\title{
Behavior factor of concrete portal frames with dissipative devices based on carbon-wrapped steel tubes
}

\author{
Andrea Vittorio Pollini ${ }^{1} \cdot$ Nicola Buratti ${ }^{1}$ (D) Claudio Mazzotti $^{1}$
}

Received: 11 October 2019 / Accepted: 7 October 2020 / Published online: 23 October 2020

(c) The Author(s) 2020

\begin{abstract}
The key element characterizing the seismic vulnerability of existing prefabricated RC structures, not designed for earthquake actions, are friction-based connections between structural members; mainly those between beams and columns and beams and roofing beams. The paper discusses the effectiveness of dissipative connectors made of carbon wrapped steel tubes. In particular, it presents the results of Incremental Dynamic Analyses on portal frames, aimed at evaluating behavior factor values to be used in design. A simplified formula for estimating the behavior factor is also proposed. Results of nonlinear IDAs suggest that the introduction of these dissipative devices in friction-based beam-column joints provides an effective connection between structural members and, in addition, reduces the forces transmitted to columns, improving the seismic behavior of the entire structure.
\end{abstract}

Keywords Precast RC buildings $\cdot$ Friction connections $\cdot$ Dissipative device $\cdot$ Behavior factor $\cdot$ Seismic retrofitting

\section{Introduction}

Precast reinforced concrete (RC) structures are widely used in many countries for one-story industrial buildings such as warehouses and factories. These structures, when designed and built without seismic-design criteria, have exhibited very high seismic vulnerability (Demartino et al. 2018), as highlighted by the 2012 Emilia earthquakes (Belleri et al. 2015; Savoia et al. 2017; Buratti et al. 2017). Considering their economic importance (Rossi et al. 2019), reducing their seismic vulnerability and, in general, the related losses in case of earthquakes, is of primary importance.

Most of the partial- and full-collapses observed during past seismic events were caused by the absence of effective mechanical connectors between structural elements, in fact, friction-based connections were widespread (Bournas et al. 2013; Liberatore et al. 2013; Magliulo et al. 2014; Belleri et al. 2015; Babič and Dolšek 2016; Savoia

Nicola Buratti

nicola.buratti@unibo.it

1 Department of Civil, Chemical, Environmental and Materials Engineering (DICAM), Alma Mater Studiorum - University of Bologna, Bologna, Italy 
et al. 2017; Demartino et al. 2018; Titi et al. 2018). The vulnerability of structures with this type of connections has been confirmed also by numerical simulations. Biondini et al. (2013a) analyzed the behavior under earthquake loads of friction-based connections by means of incremental time-history analyses. In particular, they investigated the influence of different values of the friction coefficient and of vertical of groundmotions. Titi et al. (2018) found that dry beam-column connections are associated to large relative displacements, which may lead to structural collapse, and that this condition is more likely to occur under vertical ground motions with a frequency content similar to the vertical natural frequencies of vibration of structural elements. Similar conclusions were drawn by Demartino et al. (2018). Liberatore et al. (2013) observed that vertical ground-motions, and the absence of beam-column connectors, can trigger collapses phenomena involving the unseating of beams. Magliulo et al. (2014) provided a parametric study comparing friction strength to the horizontal shear demand in connections produced by wind, according to past Italian buildings codes. Considering friction coefficients between 0.09 and 0.13 , in $25 \%$ of cases the connection capacity was exceeded by the shear demand. The authors concluded that the vulnerability of friction beam-column connections is also due to the high friction coefficient $(0.35)$ suggested by past Italian codes for the evaluation of the friction strength. If values (0.13-0.09) proposed by Magliulo et al. (2011) had been adopted in design, the use of friction connections would have been more limited. Finally, Deyanova et al. (2014) observed that the failure of beam-column connections based on friction only can frequently happen before the formation of plastic hinges at the base of columns, therefore producing non-ductile failure modes.

Given the high vulnerability of connections, many strengthening solutions have been proposed in the literature. Ligabue et al. (2014) tested L-shaped steel plates for the connection of beams and columns, Muciaccia et al. (2014) presented a study on the use of post-inserted metal anchors and fastenings, Bournas et al. (2013) proposed the use of cable restraints in order to reduce the likelihood of collapse due to unseating of beams and roofing elements. Magliulo et al. (2014) proposed beam-column mechanical connectors able to avoid the loss of support failure of beams. Del Lago et al. (2017a, b, c) have proposed to use steel angles as dissipative connection elements: these devices in fact, in spite of being very simple and relatively inexpensive, can dissipate a good amount of energy and feature a stable hysteretic behavior. Scotta et al. (2015) suggested to use cladding panels as dissipative shear walls, in fact these elements can strongly influence the seismic response of precast concrete structures (Biondini et al. 2013a). With a similar purpose Del Monte et al. (2019) have developed innovative dissipative connections for connecting cladding panels to structural elements. Belleri et al. (2017) have proposed a recentering dissipative device based on rotary friction, in order to introduce energy dissipation in hinged beam-column connections. Also Martinelli and Mulas (2010) have proposed the insertion of devices that dissipate energy through rotary friction but with no recentering capacity. Alternative solutions could be based on dampers, as suggested by Marinini et al. (2011).

The present paper refers to a low-damage solution for the retrofit of friction-based beam-column connections of existing prefabricated RC structures that employs dissipative devices based on carbon-wrapped steel tubes (CWST), described in Pollini et al. (2018). The first part of the paper presents results from a large number of incremental dynamic analyses (IDAs), aimed at estimating values for an equivalent behavior factor to be used in design applications. The last part of the paper introduces an analytical simplified approach to estimate the behavior factor, validated by comparison with the numerical simulations. 


\section{Retrofit of friction connections with dissipative devices}

The CWSTs (Pollini et al. 2018) considered in the present paper have two main purposes: (1) strengthening beam-column joints in order to prevent the possible unseating failure of beams, and (2) acting as dissipative fuses, thus reducing the effects of seismic actions on structural elements. As discussed by Pollini et al. (2018) four objectives guided their development: (1) the capacity to absorb energy in small dimensions, (2) the capacity to limit the forces transferred between structural elements, (3) the capacity to prevent the unseating of beams from columns and (4) the ease of replacement. The energy absorption mechanism of the CWSTs was derived from studies in automotive engineering on structural crashworthiness (Song et al. 2000; Lima et al. 2011), showing that metals and composite materials combined in thin-walled circular tubes have excellent capacities in terms of energy absorption under axial compressive loads.

The mode of collapse of a CWST in compression is characterized by the formation of a series of folds after the onset of buckling (concertina buckling mode), as shown in Fig. 1a for a steel tube with and without external carbon-fiber wrapping. The external composite wrapping, limits the outwards movement of the steel tube wall, until the tensile failure of carbon fibers. Because of their high strength, their usage significantly increases the value of force associated to the plastic deformation of the tubes. Furthermore, carbon fibers, by means of their confinement action, also assure a regular behavior during buckling and increase the strength of the devices, improving, consequently, their capacity to dissipate energy. The results of an experimental campaign aimed at characterizing the monotonic and cyclic behavior of the CWSTs, evaluating also their dissipation capabilities, were presented by Pollini et al. (2018).

Since each CWST works and dissipates energy only under compressive loading, two devices must be properly connected to each structural joint (Fig. 1b). A threaded bar, passing through the CWSTs, can be used both as guide during their plastic deformation and as support for attaching the devices to existing structural elements. This threaded bar can be fixed through standard anchoring elements to a column. The anchorage on beams must feature an element placed between the two devices with adequate strength and stiffness, suited for transferring forces from the beam to the CWSTs and, at the same time, capable of sliding on the threaded bar (see Fig. 2).

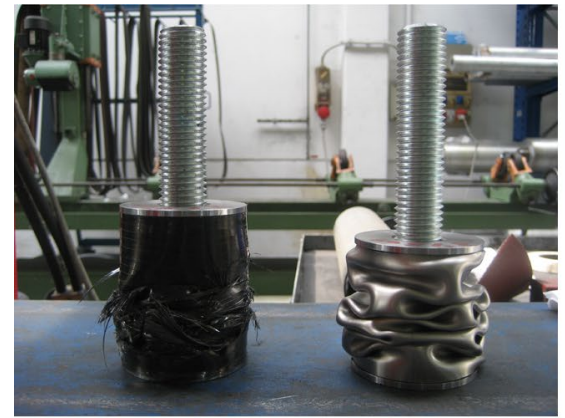

(a)

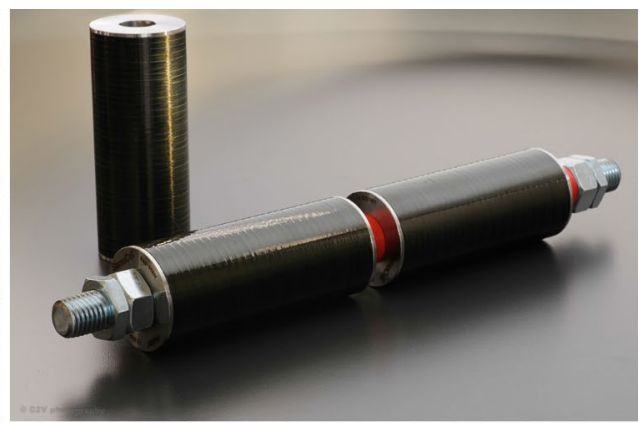

(b)

Fig. 1 Mode of collapse of steel tubes with and without carbon fiber external wrapping 

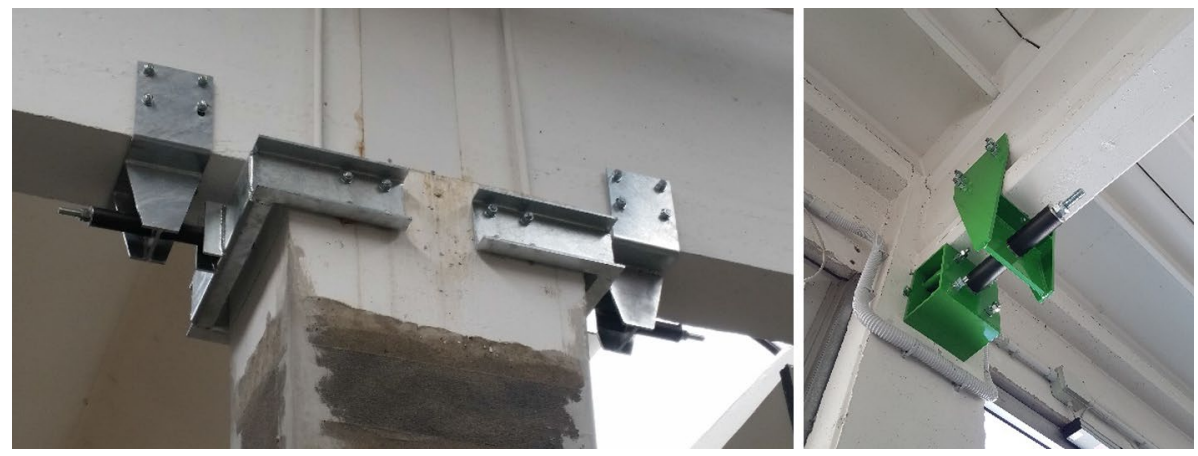

Fig. 2 Examples of beam-column connections with dissipative devices

The behavior of the devices in compression can be approximated as in Fig. 3 (Pollini et al. 2018), where $F_{e p}$ indicates their the equivalent plastic force, and $S_{\text {max }}$ their maximum deformation capacity. The behavior of a beam-column connection with CWSTs under a lateral load can be idealized as follows: as far as the force is lower than $F_{e p}$, the lateral force is fully transmitted to the column, with a very small relative beam-column displacement, because of the high initial stiffness of the devices (O-A segment in Fig. 3). As the force increases, one of the two devices (the one under compression) begins to buckle and dissipates energy during the progression of plastic deformation (A-B segment in Fig. 3). Beamcolumn relative displacement occurs until the CWST in compression reaches it maximum axial deformation capacity $S_{\max }$ and its stiffness strongly increases, thus acting as an effective displacement-limiter between structural elements through the threaded bar (B-C segment in Fig. 3). For further increasing values of applied forces, the column will then yield and subsequently reach its ultimate deformation capacity.

When considering cyclic loads, the two CWSTs installed in each connection are activated alternatively. If a load reversal occurs after compression bucking one of the steel tubes, the connection will slide with zero force until closure of the gap produced plastic deformations. Figure 4 shows a sketch of the cyclic behavior of a couple of CWSTs.

The aforementioned behavior requires that beams slide on their supports in order to dissipate energy. Therefore, it is fundamental to control friction forces, in order to: (1)

Fig. 3 Subsequent phases of the behavior a CWST under compressive loading

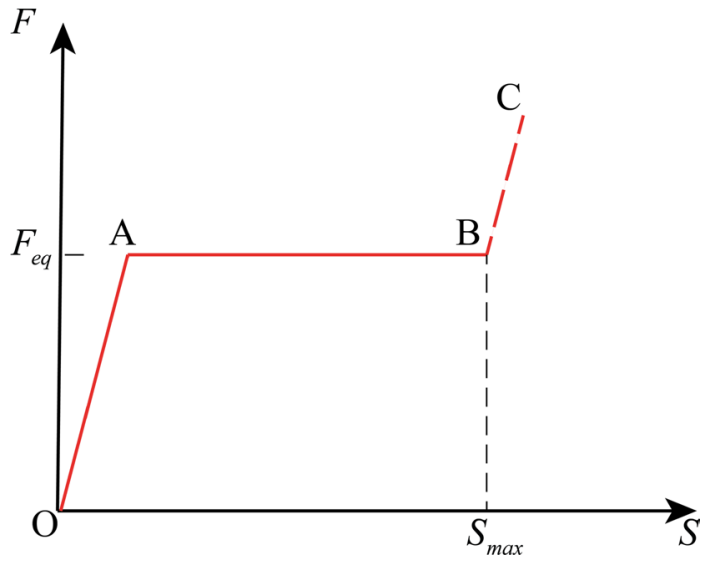




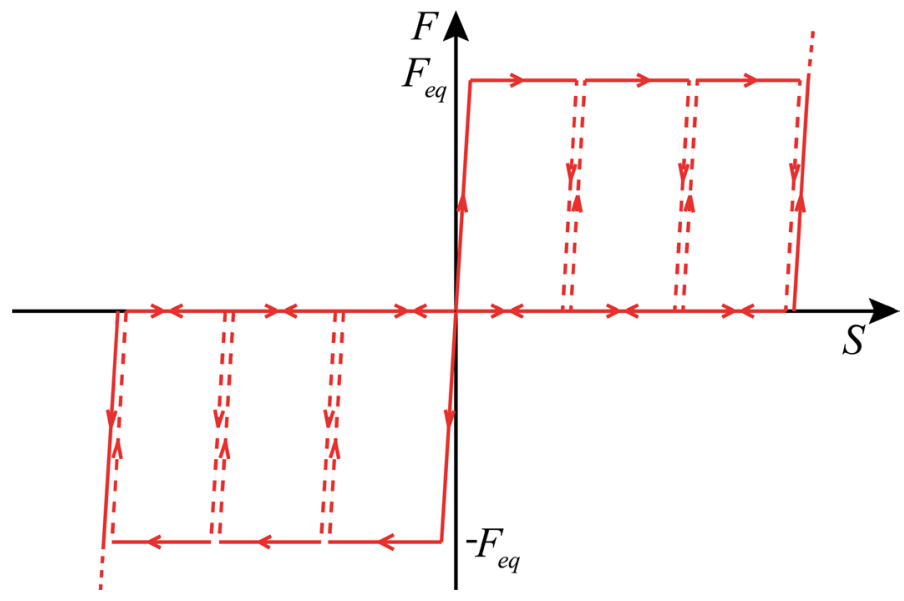

Fig. 4 Hysteretic cycle of the system composed by two devices

make sliding possible in order to dissipate energy and; (2) to control the horizontal forces transferred to columns. It is worth noticing that the effectiveness of the CWSTs mainly depends on (1) because their energy deformation capacity is limited. For these reasons, when designing retrofit interventions based on the devices discussed in the present paper, it is recommended to implement solutions (e.g. by using PTFE pads) aimed at limiting and controlling friction in beam supports. Furthermore, limiting the value of the friction coefficient will make the systems less sensitive to variations of the axial load in columns, as in case of strong vertical ground-motions. In buildings where inserting PTFE pads is either unfeasible or uneconomical the effect of friction should be carefully considered. Finally, in order to maximize the effectiveness of the CWSTs, it is convenient to maximize their maximum deformation capacity $S_{\max }$. The largest usable values for this parameter depend on the maximum allowable beam column displacement. The equivalent plastic force of the devices $F_{e q}$ should be larger than the horizontal forces to be transferred under non seismic loading conditions and smaller than the force that would lead to the formation of a plastic hinge at the base of columns, which must fail after the CWSTs. In case of concrete-onconcrete supports the friction threshold of motion can be similar or even larger than the equivalent force of plasticization of the CWSTs thus reducing their effectiveness. In fact, in these cases it might not be possible to avoid that plastic hinges form at the base of columns (unless they are strengthened) before the activation of the energy dissipation mechanism of the devices which would work as non-dissipative connectors. Finally, it is important to remark that the CWSTs considered require relative displacements between structural elements to occur in order to be effective. In some cases, this requirement might be a limitation, in particular if structural elements must be recentered after a seismic event.

\section{Case study}

Several numerical analyses were carried out on different portal-frame models, in order to define the behavior factor to be considered when designing strengthening interventions that employ CWSTs. The features of the portal-frames were defined based on a survey of the 
most widespread types of one-story precast concrete structures used in Italy for industrial buildings. Different sources were used to this purpose, such as research papers, design guidelines and standards, surveys on existing structures and interviews with producers of prefabricated concrete elements. In particular, Deyanova et al. (2014) investigated 60 buildings (40 from the Emilia-Romagna region and 20 from other regions), summarizing their main characteristics in terms of span length, column aspect ratio and beam-column connections. They reported that the most common beam span length is between 14 and $20 \mathrm{~m}$ and column aspect ratio (column height/cross-section width) is greater than 10 . Bellotti et al. (2014) presented a review of precast structural typologies and construction practices in Northern Italy, using three different databases, for a total number of 670 precast RC buildings included into the study, built in the last 5 decades. The first database has been built based on a survey carried out after the 2012 Emilia earthquakes by the Structural Analysis Research Group of Eucentre with the collaboration of Confidustria Piacenza in the Emilia-Romagna region; the second one has been collected between 2003 and 2008 by the Seismic Division of Tuscany region and the third database was assembled between 2005 and 2008 by Assobeton (Mandelli Contegni et al. 2008), a consortium of several construction companies, manufacturers of precast elements, in Italy. For industrial buildings located in the Emilia-Romagna and the Tuscany Regions, they proposed probabilistic distributions for some geometrical parameters for each structural type, such as span length of main girders and roof slab elements, and column height.

\subsection{Properties of the case study frames}

The structural type considered herein consists of cantilever columns supporting a beam, thus forming frames in the transverse direction of a building with no additional lateral force resisting system along the longitudinal direction. Therefore, the transversal behavior of these structures can be approximated as an equivalent frame. The main parameters assumed for the frame models considered are reported in Table 1. For each of these models, different configurations of beam-column joints were considered: (1) beams hinged to the columns and (2) simply supported beams with CWST, with two different values of friction coefficient $v$ for the beam support, i.e. $v=0.05$, corresponding to the insertion of PTFE pads as discussed in Sect. 2, and $\nu=0.10$ corresponding to neoprene pads, often found in existing prefabricated RC frame buildings. This second case represents structures in which it might be either unfeasible or uneconomical to insert PTFE. Clearly the friction coefficient value depends on the type of beam-column interface (concrete, rubber pads or steel plates) and its definition is still debated in the literature (Magliulo et al. 2011, 2014); the values considered here are based on experimental studies conducted by Magliulo et al. (2011) on neoprene-to-concrete connections, suggesting friction coefficients in the range of 0.09-0.13. Other types of interacting surfaces such as concrete-to-concrete were not considered because, as discussed in Sect. 2, they strongly reduce the effectiveness of the CWSTs.

The value of the equivalent force of plasticization $F_{e q}$ (see Sect. 2) for the CWSTs was chosen, as discussed in Sect. 2, as the maximum value of force that, considering a friction coefficient equal to 0.05 , could be transferred to the top of the columns without yielding their base sections, i.e. $M_{y}>\left(F_{e q}+v \cdot N\right) \cdot H$. This allows to avoid yielding of the columns before the activation of the CWSTs, a condition that would make them ineffective. For the models $\mathrm{C}$ and D two different values of $F_{e q}$ where considered, i.e. either $30 \mathrm{kN}$ or 20 $\mathrm{kN}$, the models with the lower $F_{e q}$ value are indicated as $\mathrm{C} 1$ and D1. For the models with 
Table 1 Properties of the structural models considered.

\begin{tabular}{lllllll}
\hline & Model & & & & \\
\cline { 2 - 6 } & A & B & C & C1 & D & D1 \\
\hline$L[\mathrm{~m}]$ & 12.0 & 20.0 & 25.0 & 25.0 & 20.0 & 20.0 \\
$H[\mathrm{~m}]$ & 8.0 & 7.0 & 6.0 & 6.0 & 7.0 & 7.0 \\
$i[\mathrm{~m}]$ & 6.0 & 7.0 & 8.0 & 8.0 & 10.0 & 10.0 \\
Column $b \times h[\mathrm{~m}]$ & $0.3 \times 0.4$ & $0.4 \times 0.4$ & $0.4 \times 0.5$ & $0.4 \times 0.5$ & $0.4 \times 0.6$ & $0.4 \times 0.6$ \\
Beam $b \times h[\mathrm{~m}]$ & $0.25 \times 1.25$ & $0.3 \times 1.38$ & $0.35 \times 1.85$ & $0.35 \times 1.85$ & $0.35 \times 1.47$ & $0.35 \times 1.47$ \\
Beam self weight $[\mathrm{kN}]$ & 7.72 & 10.33 & 16.21 & 16.21 & 12.88 & 12.88 \\
Beam load $(\mathrm{kN} / \mathrm{m})$ & 19.60 & 22.86 & 26.12 & 26.12 & 32.66 & 32.66 \\
$N[\mathrm{kN}]$ & 163 & 331 & 529.23 & 529.23 & 455 & 455 \\
$F_{e q}[\mathrm{kN}]$ & 10 & 20 & 30 & 20 & 30 & 20 \\
& $\nu=0.05$ & & & & & \\
$M_{y}[\mathrm{kNm}]$ & 245 & 276 & 393 & 393 & 580 & 580 \\
$M_{u}[\mathrm{kNm}]$ & 274 & 295 & 414 & 414 & 643 & 643 \\
$\phi_{y}[1 / \mathrm{m}]$ & 0.01 & 0.009933 & 0.007558 & 0.007558 & 0.00616 & 0.00616 \\
$\phi_{u}[1 / \mathrm{m}]$ & 0.279 & 0.2475 & 0.163 & 0.163 & 0.1547 & 0.1547 \\
& $\nu=0.10$ & & & & & \\
$M_{y}[\mathrm{kNm}]$ & 245 & 418 & 539 & 539 & 729 & 729 \\
$M_{u}[\mathrm{kNm}]$ & 274 & 420 & 549 & 549 & 802 & 802 \\
$\phi_{y}[1 / \mathrm{m}]$ & 0.01 & 0.00814 & 0.006365 & 0.006365 & 0.00524 & 0.00524 \\
$\phi_{u}[1 / \mathrm{m}]$ & 0.279 & 0.1815 & 0.1766 & 0.1766 & 0.1659 & 0.1659 \\
\hline
\end{tabular}

$L$ beam span, $H$ column height, $i$ distance between frames, $b$ cross section width, $h$ cross section height, $N$ axial force in each column, $M_{\mathrm{y}}$ and $\phi_{y}$ column cross-section yielding moment and curvature; $M_{u}$ and $\phi_{u}$ column cross section ultimate moment and curvature

$v=0.10$, whenever the aforementioned condition could not be fulfilled it was assumed to strengthen be bottom part of the columns, by means of concrete jacketing, in order to obtain a yielding moment at the base larger than $\left(F_{e q}+v \cdot N\right) * H$ (Table 1). Lower values of $F_{e q}$ were not considered in order to avoid the activation (i.e. onset of buckling) of the CWSTs under non seismic loads.

\subsection{The FEM model}

Time-history analyses were carried-out using the FEM software OpenSees (McKenna et al. 2010), with the model illustrated in Fig. 5. Each structural member was subdivided into 10 sub elements with lumped masses. The nonlinear behavior of the CWST in the beam-column joints were modelled using non-linear springs with proper hysteretic rules. In particular, the trilinear model proposed by Pollini et al. (2018) was adopted for the CWSTs. Friction was modelled using the flat sider bearing element, a two node element that simulates friction on a flat surface, taking into account the effect of variations in the normal force with a velocity-independent Coulomb friction model.

In all models, beams had a linear behavior because no damage is expected to occur in these elements. Rayleigh damping with 5\% damping ratio was adopted. As discussed in the following sections, two different models for columns were considered, i.e. a fully elastic 


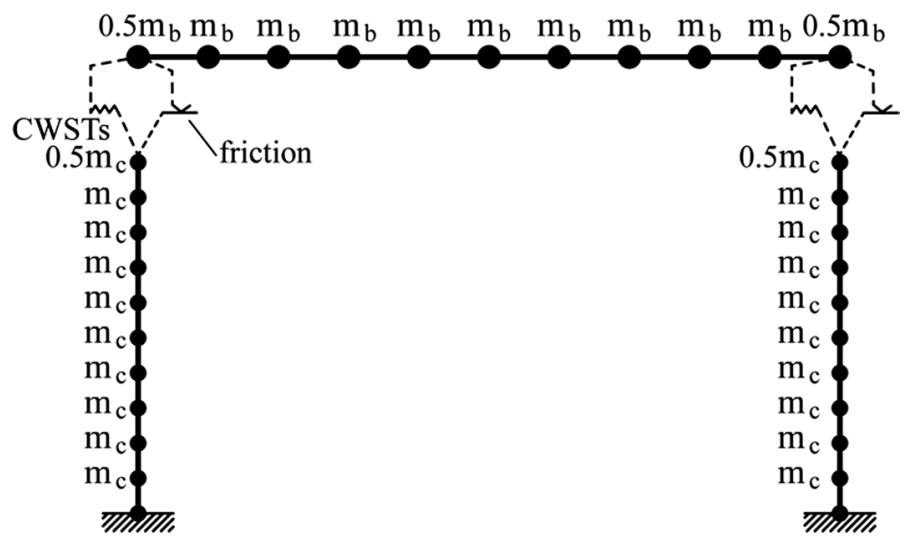

Fig. 5 Scheme of structural model used for analyses performed using OpenSees

model and a lumped plasticity model. The models with elastic columns were used in order to evaluate the effectiveness of the CWST alone.

\section{Evaluation of the behavior factor using IDA}

The aim of the numerical simulations described in this Section was evaluating an equivalent behavior factor for RC precast portal frames equipped with CWSTs, by comparing their seismic response with that of equivalent elastic structures. To this purpose, incremental dynamic analyses (IDA) were performed. The 88 couples of recorded ground-motion accelerograms (the vertical and one horizontal component) listed in Tables 11, 12 and 13 were used in the IDA analyses. In order to obtain general results, they were selected based on three different earthquake-magnitude and source-to-site distance scenarios (Bommer and Acevedo 2004): (1) moment magnitude $M_{w} \geq 6.5$ and Joyneer-Boore distance $R_{J B} \leq$ $20 \mathrm{~km}$, named large-magnitude, short-distance (LMSD); (2) $M_{w} \geq 6.5$ and $R_{J B}>20$, indicated in the following large-magnitude, long-distance (LMLD); (3) $M_{w}<6.5$ and $R_{J B} \leq$ $20 \mathrm{~km}$, referred to as small-magnitude, short-distance (SMSD). For each of these scenarios recorded accelerograms were selected based on the following criteria: (1) to have pseudospectral acceleration values larger than $1.5 \mathrm{~m} / \mathrm{sec}^{2}$ for $T=[1.0-1.5]$ for the horizontal components; (2) to use a maximum of 4 records per earthquake; (3) to have a maximum usable period of at least $3.0 \mathrm{~s}$ (Bommer and Acevedo 2004). The criterion ( $i$ ) was adopted in order to avoid large scaling factors in the IDAs. The period range considered is representative of the first natural period of vibration for precast RC structures. Tables 11, 12 and 13 also indicate which records present pulse-like features according to the procedure proposed in Baker (2007). These records were adopted in order to investigate the effect of pulse-like ground-motions on the behavior factor; in fact, this type of ground motions produce larger inelastic displacement demands on structures (MacRae et al. 2001; Mavroeidis et al. 2004) than regular ground-motions. Pulse-like ground motions were observed also during the 2012 Emilia earthquake in Italy (Savoia et al. 2017).

Two different performance targets were considered in the IDAs, based on the behavior of columns (i.e. linera or nonlinear). In particular, for models with linear columns the performance target was the maximum deformation capacity $\left(S_{\max }\right)$ of the CWSTs, while for 
models with inelastic columns the performance requirement was defined in terms of chord rotation of columns $\theta$. In order to efficiently perform the large number of analyses required, the IDA procedure was automated by means of a Matlab script. A bisection algorithm was adopted in order to identify, for each ground-motion considered, the scaling factor leading to the target performance requirement. The scaled accelerograms obtained with this procedure were then adopted to carry-out dynamic analyses on equivalent elastic frames (with hinged beam-column joints). The behavior factor for the structures containing the CWSTs was calculated as the ratio of the maximum base shear value in the equivalent elastic system over the base shear in the system with CWST.

\subsection{Behavior factor for models with elastic columns}

The aim of this first set of analyses was evaluating the capabilities of CWSTs in terms of energy dissipation and mitigation of the effects of ground-motions on columns. Values of the maximum deformation capacity (see Fig. 3) of the CWSTs spanning from 25 to $125 \mathrm{~mm}$ with increments of $25 \mathrm{~mm}$ were considered as performance targets, for a total of 5280 IDA analyses. It is worth noticing that in most existing structures it might be unpractical to adopt $S_{\max }$ values larger that $75 \mathrm{~mm}$, but here we considered also larger values in order to have a sounder parametric study.

As an example, Fig. 6 illustrates the IDAs for Model $D$, with $v=0.05$ and $S_{\max }=75 \mathrm{~mm}$ for the ground-motions from the scenario LMLR. It should be noticed that, as discussed in the previous Section, the objective of the analyses was estimating the ground-motion scaling factor associated to the performance target by means of a bisection algorithm, therefore the number of points of the IDA curves is limited.

Figure 7 shows, with reference to frame D and to one of the couples of ground-motion recordings considered, a comparison between the base shear time-histories obtained from the model with dissipative devices (CWSTs) and the equivalent elastic system, considering the ground-motion scaling factor required to reach the target displacement equal to $S_{\max }=75 \mathrm{~mm}$. The relevant reduction of the maximum base shear due to presence of CWSTs is clear. Using results from the same analysis Fig. 8 and Fig. 9 show the relative beam-column displacement and the hysteretic cycles for one couple of dissipative devices, respectively. These figures confirm the fuse-like behavior of the CWSTs, able to set a

Fig. 6 IDA curves for Model D, scenario LMLR, $\nu=0.05$, $S_{\max }=75 \mathrm{~mm}$

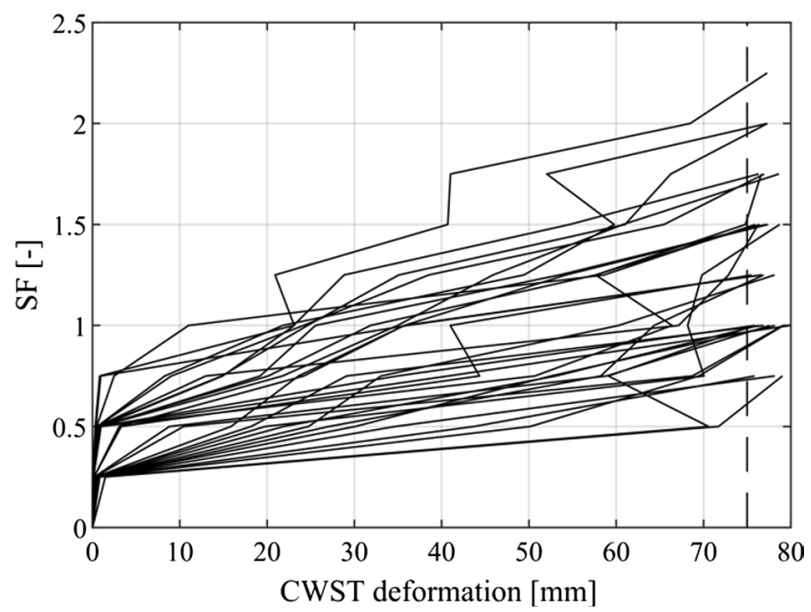


Fig. 7 Base shear values for a frame with dissipative devices and for the equivalent elastic system, Model D, scenario LMLR, accelerogram \#19, $\nu=0.05$, $S_{\max }=75 \mathrm{~mm}$

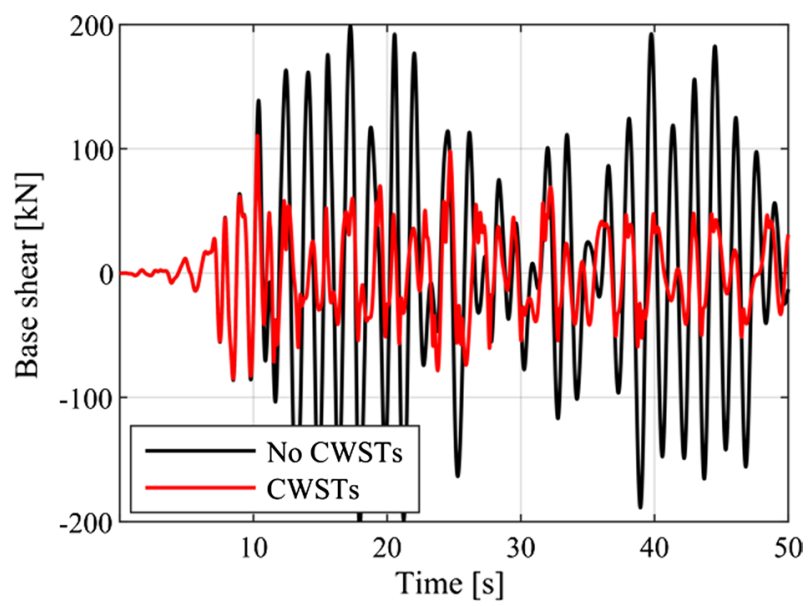

Fig. 8 Relative beam-column displacement for Model D, scenario LMLR, accelerogram \#19, $\nu=0.05, S_{\max }=75 \mathrm{~mm}$

Fig. 9 Hysteretic behavior of a couple of CWSTs devices in one of the beam-column joints for Model D, scenario LMLR, accelerogram \#19, $v=0.05$, $S_{\max }=75 \mathrm{~mm}$
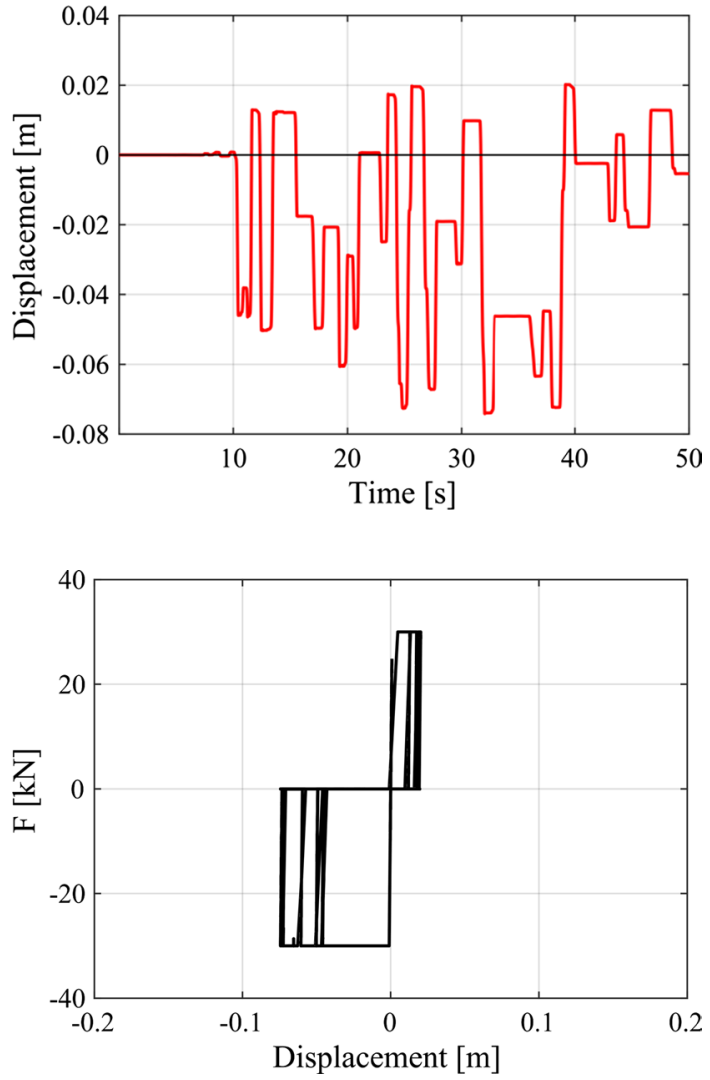

threshold force level which can be transmitted to the columns (30 $\mathrm{kN}$ in the present case). Figure 10 shows the behavior of one of the flat slider elements used to represent friction in the numerical model, in particular the friction threshold of motion $F_{t}=v N$ represents the 
Fig. 10 From top to bottom: (1) horizontal force transferred trough friction in one beam support, (2) axial force in the column, (3) friction threshold of motion. Model D, scenario LMLR, accelerogram \#19, $\nu=0.05, S_{\text {max }}=75 \mathrm{~mm}$
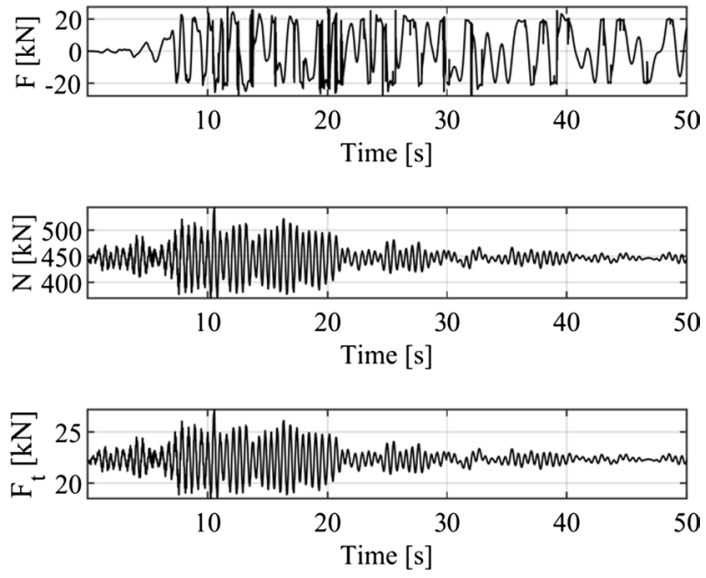

force required to have sliding, while the actual horizontal force transferred trough the element is $F$; clearly when sliding occurs $F=F_{t}$.

Tables 2 and 3 show the mean values of the behavior factor $q_{C W S T}$ obtained from the analyses for models with $v=0.05$ and $\nu=0.1$, respectively. They are reported as disaggregated data for Pulse-like (P) and Non Pulse-like (NP) ground-motions. The data in the aforementioned tables suggest that $\mathrm{P}$ ground motions are associated to a lower value of the behavior factor, on average about $-10 \%$. This is consistent with the larger displacement demands associated to pulse-like ground motions (MacRae et al. 2001; Mavroeidis et al. 2004). It is also interesting to notice that the behavior factor decreases as the friction coefficient increases. If the friction coefficient increases, the maximum base shear value in the system with CWSTs increases because the contribution of friction is added to column shear. This has a negative effect on the behavior factor values, but on the other hand when the friction coefficient increases, also the scaling factor required in order to achieve the target $S_{\max }$ value increases, thus determining a higher maximum

Table 2 Mean values of the behavior factor for models with elastic columns and $\mathrm{v}=0.05$ for Pulse-like (P), and Non-Pulse Like (NP) ground-motion records

\begin{tabular}{|c|c|c|c|c|c|c|}
\hline \multirow[t]{2}{*}{ Model } & \multirow[t]{2}{*}{ Pulse } & \multicolumn{5}{|l|}{$S_{\max }$} \\
\hline & & $25 \mathrm{~mm}$ & $50 \mathrm{~mm}$ & $75 \mathrm{~mm}$ & $100 \mathrm{~mm}$ & $125 \mathrm{~mm}$ \\
\hline \multirow[t]{2}{*}{ A } & $\mathrm{P}$ & 1.18 & 1.38 & 1.48 & 1.64 & 1.87 \\
\hline & NP & 1.13 & 1.33 & 1.53 & 1.73 & 1.86 \\
\hline \multirow[t]{2}{*}{ B } & $\mathrm{P}$ & 1.19 & 1.42 & 1.58 & 1.69 & 1.98 \\
\hline & NP & 1.15 & 1.36 & 1.56 & 1.77 & 1.92 \\
\hline \multirow[t]{2}{*}{ C } & $\mathrm{P}$ & 1.25 & 1.54 & 1.97 & 2.28 & 2.54 \\
\hline & NP & 1.35 & 1.94 & 2.47 & 2.73 & 3.10 \\
\hline \multirow[t]{2}{*}{$\mathrm{C} 1$} & $\mathrm{P}$ & 1.33 & 1.72 & 2.20 & 2.51 & 2.86 \\
\hline & NP & 1.42 & 2.14 & 2.68 & 3.08 & 3.44 \\
\hline \multirow[t]{2}{*}{ D } & $\mathrm{P}$ & 1.29 & 1.48 & 1.85 & 2.09 & 2.49 \\
\hline & NP & 1.36 & 1.83 & 2.35 & 2.70 & 3.10 \\
\hline \multirow[t]{2}{*}{ D1 } & $\mathrm{P}$ & 1.30 & 1.58 & 2.02 & 2.48 & 2.80 \\
\hline & NP & 1.43 & 2.07 & 2.57 & 3.08 & 3.53 \\
\hline
\end{tabular}


Table 3 Mean values of the behavior factor for models with elastic columns and $\mathrm{v}=0.1$ for Pulse-like (P), Non Pulse-Like (NP) ground-motion records

\begin{tabular}{|c|c|c|c|c|c|c|}
\hline \multirow[t]{2}{*}{ MODEL } & \multirow[t]{2}{*}{ Pulse } & \multicolumn{5}{|l|}{$S_{\max }$} \\
\hline & & $25 \mathrm{~mm}$ & $50 \mathrm{~mm}$ & $75 \mathrm{~mm}$ & $100 \mathrm{~mm}$ & $125 \mathrm{~mm}$ \\
\hline \multirow[t]{2}{*}{ A } & $\mathrm{P}$ & 1.14 & 1.27 & 1.41 & 1.45 & 1.56 \\
\hline & NP & 1.09 & 1.25 & 1.38 & 1.51 & 1.64 \\
\hline \multirow[t]{2}{*}{ B } & $\mathrm{P}$ & 1.13 & 1.31 & 1.43 & 1.58 & 1.74 \\
\hline & NP & 1.17 & 1.38 & 1.67 & 1.88 & 2.21 \\
\hline \multirow[t]{2}{*}{$\mathrm{C}$} & $\mathrm{P}$ & 1.27 & 1.51 & 1.79 & 2.30 & 2.60 \\
\hline & NP & 1.32 & 1.75 & 2.23 & 2.58 & 2.87 \\
\hline \multirow[t]{2}{*}{$\mathrm{C} 1$} & $\mathrm{P}$ & 1.27 & 1.59 & 1.98 & 2.46 & 2.79 \\
\hline & NP & 1.36 & 1.88 & 2.38 & 2.75 & 3.11 \\
\hline \multirow[t]{2}{*}{ D } & $\mathrm{P}$ & 1.28 & 1.48 & 1.70 & 1.98 & 2.39 \\
\hline & NP & 1.30 & 1.66 & 2.06 & 2.43 & 2.72 \\
\hline \multirow[t]{2}{*}{ D1 } & $\mathrm{P}$ & 1.33 & 1.55 & 1.89 & 2.21 & 2.61 \\
\hline & NP & 1.37 & 1.79 & 2.22 & 2.62 & 2.91 \\
\hline
\end{tabular}

base shear value of the equivalent elastic system and therefore increasing the behavior factor value. Generally, in analyses with linear columns, the first effect is prevailing, and the behavior factor tends to decrease considering friction in beam-column joints. Furthermore, it is possible to notice that, as expected, the behavior factor increases with increasing values of $S_{\max }$, in fact larger maximum displacement capacities of the CWSTs always correspond to larger scaling factor for the ground motions. It is also interesting to compare the results of the models $\mathrm{C} 1$ and $\mathrm{D} 1$ with those of $\mathrm{C}$ and $\mathrm{D}$, respectively, since the only difference between these models is the value of $F_{e q}$. Table 4 shows the relative difference between these results, computed as $\Delta_{C 1-C}=\mathrm{q}_{\mathrm{CWST}}^{\mathrm{Cl}} / \mathrm{q}_{\mathrm{CWST}}^{\mathrm{C}}-1$ with reference to models $\mathrm{C} 1$ and $\mathrm{C}$ and analogously for D1 and D. The results of the analyses indicate that the models with a smaller value of $F_{e q}$ have higher values of the behavior factor suggesting that the effectiveness of the CWSTs considered here is mostly due to the possibility of having relative displacement between beams and columns rather than to their actual energy dissipation capacity (see also Sect. 2).

Table 4 Comparison between the results of the models C-C1 and D-D1

\begin{tabular}{|c|c|c|c|c|c|c|}
\hline \multicolumn{7}{|c|}{$v=0.05$} \\
\hline \multirow[t]{2}{*}{$\Delta_{\mathrm{C} 1-\mathrm{C}}$} & $\mathrm{P}$ & $6.4 \%$ & $11.7 \%$ & $11.7 \%$ & $10.1 \%$ & $12.6 \%$ \\
\hline & NP & $5.2 \%$ & $10.3 \%$ & $8.5 \%$ & $12.8 \%$ & $11.0 \%$ \\
\hline \multirow[t]{2}{*}{$\Delta_{\mathrm{D} 1-\mathrm{D}}$} & $\mathrm{P}$ & $0.8 \%$ & $6.8 \%$ & $9.2 \%$ & $18.7 \%$ & $12.4 \%$ \\
\hline & NP & $5.1 \%$ & $13.1 \%$ & $9.4 \%$ & $14.1 \%$ & $13.9 \%$ \\
\hline \multicolumn{7}{|l|}{$v=0.1$} \\
\hline \multirow[t]{2}{*}{$\Delta_{\mathrm{C} 1-\mathrm{C}}$} & $\mathrm{P}$ & $0.0 \%$ & $5.3 \%$ & $10.6 \%$ & $7.0 \%$ & $7.3 \%$ \\
\hline & NP & $3.0 \%$ & $7.4 \%$ & $6.7 \%$ & $6.6 \%$ & $8.4 \%$ \\
\hline \multirow[t]{2}{*}{$\Delta_{\mathrm{D} 1-\mathrm{D}}$} & $\mathrm{P}$ & $3.9 \%$ & $4.7 \%$ & $11.2 \%$ & $11.6 \%$ & $9.2 \%$ \\
\hline & NP & $5.4 \%$ & $7.8 \%$ & $7.8 \%$ & $7.8 \%$ & $7.0 \%$ \\
\hline
\end{tabular}




\subsection{Models with inelastic columns}

In this second group of IDAs, the inelastic behavior of columns was introduced, in order to consider their energy dissipation capacity. Columns were modelled using a lumped plasticity model, without cyclic degradation. A mean compressive strength of $50 \mathrm{MPa}$ was considered for concrete as well as a mean yield strength of $500 \mathrm{MPa}$ for the steel reinforcement. The moment-curvature diagram of the base section of columns and their ultimate chord rotation was computed, for the different models, following recommendations by Priestley et al. (2007) using the software Cumbia. Concrete confinement was evaluated according to the Mander model (Mander et al. 1989). Two different values of ultimate chord rotation $\theta_{u}$ were adopted as target performance for IDA analyses, i.e. $3 \%$ and $4.5 \%$. Table 1 reports the coordinates of the yielding and ultimate point of the moment curvature diagrams for the models considered.

A first set of IDAs were performed considering hinged beam column connections. The corresponding behavior factor, indicated with $q_{c o l}$, was computed as the ratio between the maximum total base shear $\left(F_{e l, c o l}\right)$ of an equivalent elastic system (with the same natural period of vibration) and of the system with inelastic columns $\left(F_{u, c o l}\right)$. Table 5 reports the mean value of the results obtained for the portal frames under consideration, disaggregating data for $\mathrm{P}$ and NP ground motions. It can be noticed that, as observed in the previous Section, $\mathrm{P}$ ground-motions are associated to $q_{c o l}$ values that are smaller that those for NP ground motions, the decrease depend on the model considered but on average is about $10 \%$.

A further set of analyses were performed considering inelastic columns with CSWTs in beam column connections. Five different values for $S_{\max }$ were used, i.e. 25, 50, 75, 100 and $125 \mathrm{~mm}$, as well as the two different ultimate chord rotation values and friction coefficients discussed above, for a total of 10,560 IDAs.

Tables 6 and 7 report the mean behavior factor values obtained from these analyses, indicated in the following as $q_{c o l+C W S T}$. This parameter depends both on the effect of dissipative devices CWST and on plastic hinges developing at the base of the columns. As expected, $q_{c o l+C W S T}$ values are larger than the corresponding $q_{c o l}$ values and increase as $S_{\text {max }}$ increases. In fact, larger values of this parameter are associated to a larger gap opening in the devices, due to their crushing in compression, and, therefore, imply larger ground-motion scaling factors in order to achieve the ultimate chord rotation of columns. It is worth noticing that the base shear at the ultimate chord rotation of columns is equal for systems with and without CWSTs, depending only on the forcedeformation relationship of columns.

Table 5 Mean values of the $q_{\text {col }}$ behavior factor for models with hinged beam-column connections, for different ultimate chord rotations

\begin{tabular}{llll}
\hline Model & $\theta_{u}(\%)$ & \multicolumn{2}{l}{ Pulse like } \\
\cline { 3 - 4 } & & $\mathrm{P}$ & $\mathrm{NP}$ \\
\hline $\mathrm{A}$ & 3.00 & 1.20 & 1.23 \\
$\mathrm{~A}$ & 4.50 & 1.98 & 1.89 \\
$\mathrm{~B}$ & 3.00 & 1.73 & 1.58 \\
$\mathrm{~B}$ & 4.50 & 2.51 & 2.49 \\
$\mathrm{C}, \mathrm{C} 1$ & 3.00 & 2.16 & 2.58 \\
$\mathrm{C}, \mathrm{C} 1$ & 3.50 & 3.26 & 3.77 \\
$\mathrm{D}, \mathrm{D} 1$ & 3.00 & 2.01 & 2.43 \\
D, D1 & 4.50 & 3.20 & 3.90 \\
\hline
\end{tabular}


Table 6 Mean values of the $q_{\text {col+CWST }}$ behavior factor for models with inelastic columns and $\mathrm{v}=0.05$, for Pulse-like (P) and Non Pulse Like (NP) ground-motion records

\begin{tabular}{llllllll}
\hline Model & $\theta_{u}(\%)$ & Pulse & $S_{\max }$ & & & & \\
\cline { 3 - 7 } & & & $25 \mathrm{~mm}$ & $50 \mathrm{~mm}$ & $75 \mathrm{~mm}$ & $100 \mathrm{~mm}$ & $125 \mathrm{~mm}$ \\
\hline $\mathrm{A}$ & \multirow{2}{*}{3.00} & $\mathrm{P}$ & 1.54 & 1.72 & 1.88 & 2.07 & 2.17 \\
& & $\mathrm{NP}$ & 1.55 & 1.80 & 1.98 & 2.16 & 2.32 \\
& \multirow{2}{*}{4.50} & $\mathrm{P}$ & 2.16 & 2.32 & 2.52 & 2.70 & 2.85 \\
& & $\mathrm{NP}$ & 2.19 & 2.41 & 2.64 & 2.84 & 2.91 \\
$\mathrm{~B}$ & \multirow{2}{*}{3.00} & $\mathrm{P}$ & 2.07 & 2.35 & 2.45 & 2.60 & 2.67 \\
& & $\mathrm{NP}$ & 1.96 & 2.27 & 2.49 & 2.61 & 2.68 \\
& 4.50 & $\mathrm{P}$ & 2.85 & 3.09 & 3.28 & 3.19 & 3.22 \\
& & $\mathrm{NP}$ & 2.82 & 3.05 & 3.20 & 3.32 & 3.30 \\
$\mathrm{C}$ & 3.00 & $\mathrm{P}$ & 2.73 & 3.03 & 3.38 & 3.66 & 3.78 \\
& & $\mathrm{NP}$ & 3.24 & 3.59 & 3.94 & 4.20 & 4.36 \\
& \multirow{2}{*}{4.50} & $\mathrm{P}$ & 3.56 & 3.85 & 4.04 & 4.15 & 4.31 \\
& & $\mathrm{NP}$ & 4.23 & 4.52 & 4.74 & 4.81 & 4.86 \\
$\mathrm{C} 1$ & 3.00 & $\mathrm{P}$ & 2.89 & 3.24 & 3.64 & 3.94 & 4.13 \\
& & $\mathrm{NP}$ & 3.26 & 3.80 & 4.26 & 4.73 & 4.94 \\
& \multirow{2}{*}{4.50} & $\mathrm{P}$ & 3.68 & 4.03 & 4.30 & 4.61 & 4.82 \\
& & $\mathrm{NP}$ & 4.31 & 4.73 & 5.04 & 5.21 & 5.44 \\
$\mathrm{D}$ & \multirow{2}{*}{3.00} & $\mathrm{P}$ & 2.48 & 2.82 & 3.12 & 3.42 & 3.76 \\
& & $\mathrm{NP}$ & 3.01 & 3.53 & 3.96 & 4.31 & 4.70 \\
& \multirow{2}{*}{4.50} & $\mathrm{P}$ & 3.59 & 3.87 & 4.08 & 4.33 & 4.53 \\
& & $\mathrm{NP}$ & 4.31 & 4.71 & 5.11 & 5.41 & 5.65 \\
$\mathrm{D} 1$ & 3.00 & $\mathrm{P}$ & 2.51 & 2.83 & 3.22 & 3.49 & 3.87 \\
& & $\mathrm{NP}$ & 3.03 & 3.54 & 3.98 & 4.35 & 4.70 \\
& \multirow{2}{*}{4.50} & $\mathrm{P}$ & 3.63 & 3.86 & 4.16 & 4.49 & 4.54 \\
& & $\mathrm{NP}$ & 4.35 & 4.75 & 5.11 & 5.47 & 5.65 \\
\hline & & & & & & &
\end{tabular}

The data in Tables 6 and 7 confirm that $\mathrm{P}$ ground-motions, on average, are associated to behavior factor values $10 \%$ smaller than those of NP ground-motions. The increment in terms of behavior factor due to the introduction of the CWST can be measured by comparing data in Table 4 with data in Tables 6 and 7. To this purpose, Tables 8 and 9 show the relative increment of the mean behavior factor, computed as $\left(q_{c o l+C W S T} q_{c o l}-1.0\right)$. Obviously, this parameter increases with Smax, but it is interesting to notice that it decreases when passing from $\theta_{u}=3 \%$ to $\theta_{u}=4.5$. In other words, CWSTs tend to be more effective when their maximum displaceent capacity is large compared to the ultimate displacement of columns.

Figure 11 shows histograms of the $q_{c o l+C W S T}$ values for $\mathrm{P}$ and NP ground-motions, obtained form all the IDA analyses, comparing the data distributions with lognormal probability density functions (PDF). Thick lines indicate the mean value of the distributions. The variability of $q_{\text {col }+ \text { CWST }}$ is very high but it should be noticed that different structural models and friction coeffcient values are considered together. Furthermore, the data presented here are consistent with the values of record-to-record variability in the literature (Jalayer and Cornell 2009; Bradley 2013; Bovo and Buratti 2019). Figures 12 and 13 show histograms of the $q_{\text {col }+ \text { CWST }}$ values for different $S_{\text {max }}$ values, obtained form the analyses with $\theta_{u}=3 \%$ and $\theta_{u}=4.5 \%$, respetively. These plot confirm that pulse-like ground motions tend to reduce the behaviour factor, on average by $10-15 \%$ and that this reducion is independent on $S_{\max }$ 
Table 7 Mean values of the $q_{\text {col+CWST }}$ behavior factor for models with inelastic columns and $\mathrm{v}=0.10$, for Pulse-like $(\mathrm{P})$ and Non Pulse Like (NP)

\begin{tabular}{|c|c|c|c|c|c|c|c|}
\hline \multirow[t]{2}{*}{ Model } & \multirow[t]{2}{*}{$\theta_{u}(\%)$} & \multirow[t]{2}{*}{ Pulse } & \multicolumn{5}{|l|}{$S_{\max }$} \\
\hline & & & $25 \mathrm{~mm}$ & mean & mean & mean & $25 \mathrm{~mm}$ \\
\hline \multirow[t]{4}{*}{ A } & \multirow[t]{2}{*}{3.00} & $\mathrm{P}$ & 1.54 & 1.71 & 1.89 & 1.98 & 2.12 \\
\hline & & NP & 1.54 & 1.77 & 1.90 & 2.03 & 2.14 \\
\hline & \multirow[t]{2}{*}{4.50} & $\mathrm{P}$ & 2.15 & 2.34 & 2.45 & 2.63 & 2.80 \\
\hline & & NP & 2.21 & 2.42 & 2.59 & 2.78 & 2.82 \\
\hline \multirow[t]{4}{*}{ B } & \multirow[t]{2}{*}{3.00} & $\mathrm{P}$ & 2.19 & 2.45 & 2.60 & 2.83 & 2.92 \\
\hline & & NP & 2.69 & 3.08 & 3.33 & 3.54 & 3.67 \\
\hline & \multirow[t]{2}{*}{4.50} & $\mathrm{P}$ & 3.20 & 3.37 & 3.44 & 3.57 & 3.73 \\
\hline & & NP & 3.77 & 4.03 & 4.26 & 4.49 & 4.55 \\
\hline \multirow[t]{4}{*}{ C } & \multirow[t]{2}{*}{3.00} & $\mathrm{P}$ & 3.03 & 3.57 & 3.98 & 4.18 & 4.37 \\
\hline & & NP & 3.53 & 4.02 & 4.33 & 4.61 & 4.73 \\
\hline & \multirow[t]{2}{*}{4.50} & $\mathrm{P}$ & 4.33 & 4.71 & 5.08 & 5.33 & 5.40 \\
\hline & & NP & 4.81 & 5.16 & 5.35 & 5.61 & 5.73 \\
\hline \multirow[t]{4}{*}{ C1 } & \multirow[t]{2}{*}{3.00} & $\mathrm{P}$ & 3.15 & 3.69 & 4.12 & 4.40 & 4.61 \\
\hline & & NP & 3.63 & 4.19 & 4.48 & 4.77 & 4.91 \\
\hline & \multirow[t]{2}{*}{4.50} & $\mathrm{P}$ & 4.48 & 4.75 & 5.22 & 5.33 & 5.47 \\
\hline & & NP & 4.95 & 5.25 & 5.49 & 5.70 & 5.71 \\
\hline \multirow[t]{4}{*}{ D } & \multirow[t]{2}{*}{3.00} & $\mathrm{P}$ & 3.01 & 3.43 & 3.76 & 4.12 & 4.33 \\
\hline & & NP & 3.34 & 3.86 & 4.25 & 4.51 & 4.76 \\
\hline & \multirow[t]{2}{*}{4.50} & $\mathrm{P}$ & 4.30 & 4.72 & 4.83 & 5.13 & 5.44 \\
\hline & & NP & 4.78 & 5.19 & 5.51 & 5.85 & 5.99 \\
\hline \multirow[t]{4}{*}{ D1 } & \multirow[t]{2}{*}{3.00} & $\mathrm{P}$ & 3.05 & 3.53 & 3.95 & 4.21 & 4.43 \\
\hline & & NP & 3.38 & 3.96 & 4.32 & 4.59 & 4.95 \\
\hline & \multirow[t]{2}{*}{4.50} & $\mathrm{P}$ & 4.35 & 4.77 & 4.94 & 5.23 & 5.62 \\
\hline & & NP & 4.78 & 5.24 & 5.56 & 6.00 & 6.10 \\
\hline
\end{tabular}

\section{Simplified estimation of the behavior factor}

The present section introduces a simplified design-oriented approach aimed at estimating the behavior factor for a structure equipped with CWSTs in beam-column joints and compares the so obtained estimates with the results of the IDAs analyses previously discussed. The simplified procedure is based on the equal displacement assumption, as illustrated in Fig. 14, and on the hypothesis that $F_{e q}<F_{y, c o l}$. Therefore, columns are assumed to have a linear elastic behavior before yielding of CWSTs. In Fig. 10, $F_{e, c o l}$ and $F_{e, c o l+C W S T}$ indicate the maximum base shear of equivalent elastic systems, corresponding to portal frames with hinged beam-column connections, with maximum displacements equal to that of a portal frame with non-linear columns and with non-linear columns and CWSTs, respectively. $F_{y, c o l}$ and $\Delta_{y, \text { col }}$ are the column yielding force and displacement; $\Delta_{u, c o l}$ and $\Delta_{u, c o l+C W S T}$ are the ultimate beam displacements of portal frames with hinged connections and with CWSTs, respectively. The ultimate displacement of a structure equipped CWSTs, $\Delta_{u, c o l+C W S T}$, can be written as the sum of the ultimate column displacement $\Delta_{u, c o l}$ and the maximum deformation capacity of the dissipative device $S_{\max }$ : 
Table 8 Relative increment of the behavior factor values due to the introduction of CWSTs in the models with nonlinear columns and $v=0.05$

\begin{tabular}{|c|c|c|c|c|c|c|c|}
\hline \multirow[t]{2}{*}{ Model } & \multirow{2}{*}{$\begin{array}{l}\text { Target } \\
\text { damage } \\
(\%)\end{array}$} & \multirow[t]{2}{*}{ Pulse } & \multicolumn{5}{|l|}{$\mathrm{S}_{\max }$} \\
\hline & & & $25 \mathrm{~mm}(\%)$ & $50 \mathrm{~mm}(\%)$ & $75 \mathrm{~mm}(\%)$ & $100 \mathrm{~mm}(\%)$ & $125 \mathrm{~mm}(\%)$ \\
\hline \multirow[t]{4}{*}{ A } & \multirow[t]{2}{*}{3.00} & $\mathrm{P}$ & 28 & 43 & 56 & 73 & 80 \\
\hline & & NP & 26 & 46 & 61 & 76 & 89 \\
\hline & \multirow[t]{2}{*}{4.50} & $\mathrm{P}$ & 9 & 17 & 27 & 37 & 44 \\
\hline & & NP & 16 & 28 & 40 & 50 & 55 \\
\hline \multirow[t]{4}{*}{ B } & \multirow[t]{2}{*}{3.00} & $\mathrm{P}$ & 19 & 35 & 41 & 50 & 54 \\
\hline & & NP & 23 & 43 & 57 & 65 & 69 \\
\hline & \multirow[t]{2}{*}{4.50} & $\mathrm{P}$ & 13 & 23 & 31 & 27 & 28 \\
\hline & & NP & 13 & 22 & 28 & 33 & 32 \\
\hline \multirow[t]{4}{*}{$\mathrm{C}$} & \multirow[t]{2}{*}{3.00} & $\mathrm{P}$ & 26 & 40 & 57 & 70 & 75 \\
\hline & & NP & 25 & 39 & 53 & 63 & 69 \\
\hline & \multirow[t]{2}{*}{4.50} & $\mathrm{P}$ & 9 & 18 & 24 & 27 & 32 \\
\hline & & NP & 12 & 20 & 26 & 28 & 29 \\
\hline \multirow[t]{4}{*}{ C1 } & \multirow[t]{2}{*}{3.00} & $\mathrm{P}$ & 34 & 50 & 69 & 83 & 91 \\
\hline & & NP & 27 & 47 & 65 & 83 & 91 \\
\hline & \multirow[t]{2}{*}{4.50} & $\mathrm{P}$ & 13 & 24 & 32 & 41 & 48 \\
\hline & & NP & 14 & 26 & 34 & 38 & 44 \\
\hline \multirow[t]{4}{*}{ D } & \multirow[t]{2}{*}{3.00} & $\mathrm{P}$ & 23 & 40 & 55 & 70 & 87 \\
\hline & & $\mathrm{NP}$ & 24 & 45 & 63 & 77 & 93 \\
\hline & \multirow[t]{2}{*}{4.50} & $\mathrm{P}$ & 12 & 21 & 27 & 35 & 42 \\
\hline & & NP & 11 & 21 & 31 & 39 & 45 \\
\hline \multirow[t]{4}{*}{ D1 } & \multirow[t]{2}{*}{3.00} & $\mathrm{P}$ & 25 & 41 & 60 & 73 & 93 \\
\hline & & NP & 25 & 46 & 64 & 79 & 93 \\
\hline & \multirow[t]{2}{*}{4.50} & $\mathrm{P}$ & 13 & 21 & 30 & 40 & 42 \\
\hline & & $\mathrm{NP}$ & 12 & 22 & 31 & 40 & 45 \\
\hline
\end{tabular}

$$
\Delta_{u, c o l+C W S T}=\Delta_{u, c o l}+S_{\max }
$$

Based on the equal displacement approximation, it is possible to write the following proportion,

$$
\frac{F_{e, c o l}}{\Delta_{u, c o l}}=\frac{F_{e, c o l+C W S T}}{\Delta_{u, c o l+C W S T}}
$$

which, combined with Eq. (1), gives the following relationship:

$$
F_{e, c o l+C W S T}=F_{e, c o l} \cdot \frac{\Delta_{u, c o l+C W S T}}{\Delta_{u, C W S T}}=F_{e, c o l} \cdot\left(1+\frac{S_{\max }}{\Delta_{u, c o l}}\right)
$$

The behavior factor can therefore be estimated as: 
Table 9 Relative increment of the behavior factor values due to the introduction of CWSTs in the models with nonlinear columns and $v=0.1$

\begin{tabular}{|c|c|c|c|c|c|c|c|}
\hline \multirow[t]{2}{*}{ Model } & \multirow{2}{*}{$\begin{array}{l}\text { Target } \\
\text { damage } \\
(\%)\end{array}$} & \multirow[t]{2}{*}{ Pulse } & \multicolumn{5}{|l|}{$\mathrm{S}_{\max }$} \\
\hline & & & $25 \mathrm{~mm}(\%)$ & $50 \mathrm{~mm}(\%)$ & $75 \mathrm{~mm}(\%)$ & $100 \mathrm{~mm}(\%)$ & $125 \mathrm{~mm}(\%)$ \\
\hline \multirow[t]{4}{*}{ A } & \multirow[t]{2}{*}{3.00} & $\mathrm{P}$ & 29 & 43 & 57 & 65 & 76 \\
\hline & & $\mathrm{NP}$ & 25 & 44 & 54 & 65 & 74 \\
\hline & \multirow[t]{2}{*}{4.50} & $\mathrm{P}$ & 9 & 18 & 24 & 33 & 41 \\
\hline & & NP & 17 & 28 & 38 & 47 & 49 \\
\hline \multirow[t]{4}{*}{ B } & \multirow[t]{2}{*}{3.00} & $\mathrm{P}$ & 26 & 40 & 49 & 62 & 67 \\
\hline & & NP & 34 & 53 & 65 & 76 & 83 \\
\hline & \multirow[t]{2}{*}{4.50} & $\mathrm{P}$ & 8 & 14 & 17 & 21 & 26 \\
\hline & & NP & 11 & 19 & 26 & 32 & 34 \\
\hline \multirow[t]{4}{*}{$\mathrm{C}$} & \multirow[t]{2}{*}{3.00} & $\mathrm{P}$ & 22 & 43 & 60 & 68 & 76 \\
\hline & & NP & 20 & 36 & 47 & 57 & 61 \\
\hline & \multirow[t]{2}{*}{4.50} & $\mathrm{P}$ & 15 & 25 & 35 & 42 & 44 \\
\hline & & NP & 13 & 22 & 26 & 32 & 35 \\
\hline \multirow[t]{4}{*}{$\mathrm{C} 1$} & \multirow[t]{2}{*}{3.00} & $\mathrm{P}$ & 26 & 48 & 66 & 76 & 85 \\
\hline & & NP & 23 & 42 & 52 & 62 & 67 \\
\hline & \multirow[t]{2}{*}{4.50} & $\mathrm{P}$ & 19 & 27 & 39 & 42 & 46 \\
\hline & & NP & 17 & 24 & 30 & 34 & 35 \\
\hline \multirow[t]{4}{*}{ D } & \multirow[t]{2}{*}{3.00} & $\mathrm{P}$ & 23 & 41 & 54 & 69 & 77 \\
\hline & & NP & 20 & 39 & 53 & 62 & 72 \\
\hline & \multirow[t]{2}{*}{4.50} & $\mathrm{P}$ & 18 & 30 & 32 & 41 & 49 \\
\hline & & NP & 16 & 26 & 34 & 42 & 46 \\
\hline \multirow[t]{4}{*}{ D1 } & \multirow[t]{2}{*}{3.00} & $\mathrm{P}$ & 25 & 45 & 62 & 73 & 82 \\
\hline & & NP & 22 & 43 & 56 & 65 & 78 \\
\hline & \multirow[t]{2}{*}{4.50} & $P$ & 19 & 31 & 36 & 44 & 54 \\
\hline & & NP & 16 & 27 & 35 & 46 & 48 \\
\hline
\end{tabular}

Fig. 11 Distribution of $q_{\text {col+CWST }}$ considering data from all the analyses. Pulse like ground motions are in black while non-pulse like ground motions are in red. Thin lines represent a lognormal distribution and thick lines are their mean values

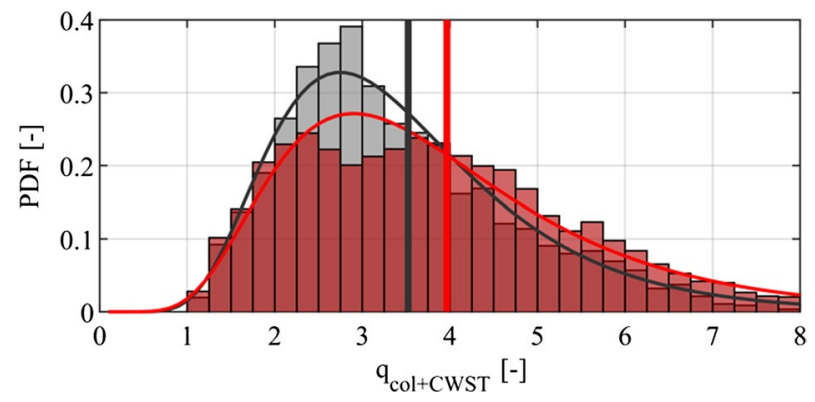

$$
q_{c o l+C W S T}^{*}=\frac{F_{e, c o l+C W S T}}{F_{y, c o l}}=\frac{F_{e, c o l}}{F_{y, c o l}} \cdot\left(1+\frac{S_{\max }}{\Delta_{u, c o l}}\right)=q_{c o l} \cdot\left(1+\frac{S_{\max }}{\Delta_{u, c o l}}\right)
$$


Fig. 12 Distribution of $q_{\text {col }+C W S T}$ from the analyses with $\theta_{u}=3.0 \%$ as a function of $S_{\max }$. Data obtained from pulse like ground motions are in black while data for non-pulse like motions are in red. Thin lines are lognormal distributions, thick lines indicate mean values
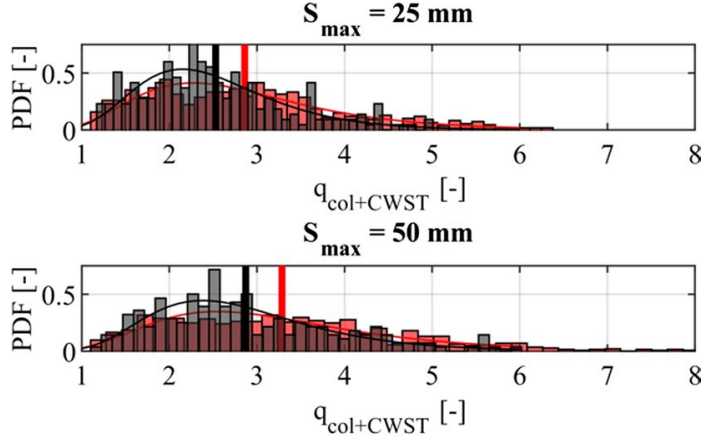

$\mathrm{S}_{\max }=75 \mathrm{~mm}$

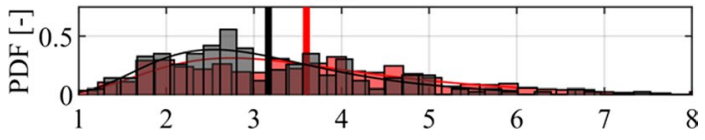

$\mathrm{q}_{\text {col }+ \text { CWST }}[-]$

$S_{\max }=100 \mathrm{~mm}$

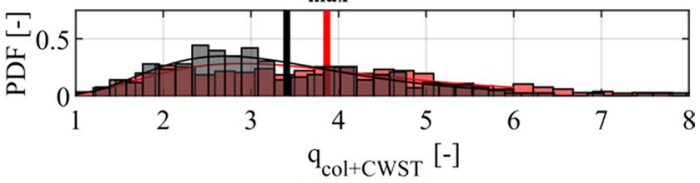

$\mathrm{S}_{\text {max }}=125 \mathrm{~mm}$

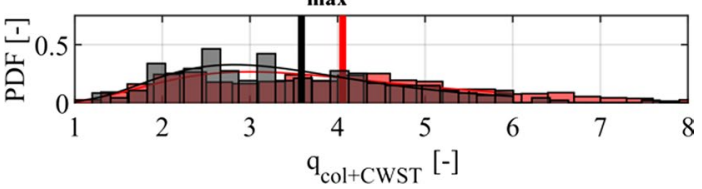

The simple formula proposed above was validated by comparing its predictions against the results of IDA analyses (see Sect. 4). Figure 15a shows a comparison considering all the results from the analyses. It can be noticed that, in general, on average the predictions form Eq. (4) are in good agreement with the average results of numerical analyses, even if in Eq. (4) slightly underestimates the behavior factor. In order to increase the goodness of the estimate, Eq. (4) was modified introducing two regression coefficients $\alpha_{1}$ and $\alpha_{2}$, as follows

$$
q_{\text {col }+ \text { CWST }}^{*}=q_{c o l}^{\alpha_{1}} \cdot\left(1+\frac{S_{\max }}{\Delta_{u, c o l}}\right)^{\alpha_{2}}
$$

The values of these parameters were estimated by means of regression analysis on the IDA results, obtaining $\alpha_{1}=0.0977$ and $\alpha_{2}=1.249$. Figure 15b shows a comparison between the results of Eq. (5) and IDA analyses. The introduction of the empirical coefficients allowed to remove any bias from the prediction. Figure 16 shows the distributions of $q^{*}$ col+CWST values from Eqs. (4) to (5) in comparison with results of the IDA analyses. It is clear that, even if the mean prediction error is low data remains very scattered, but the variability of results is consistent with that of design oriented formulas for estimating the displacement of nonlinear structures available in the literature (Guerrini et al. 2017). Nevertheless, the reader should 
Fig. 13 Distribution of $q_{\text {col+CWST }}$ from the analyses with $\theta_{u}=4.5 \%$ as a function of $S_{\max }$. Data obtained from pulse like ground motions are in black while data for non-pulse like motions are in red. Thin lines are lognormal distributions, thick lines indicate mean values

Fig. 14 Idealized force displacement relationships based on the equal-displacement assumption used for estimating the behavior factor values
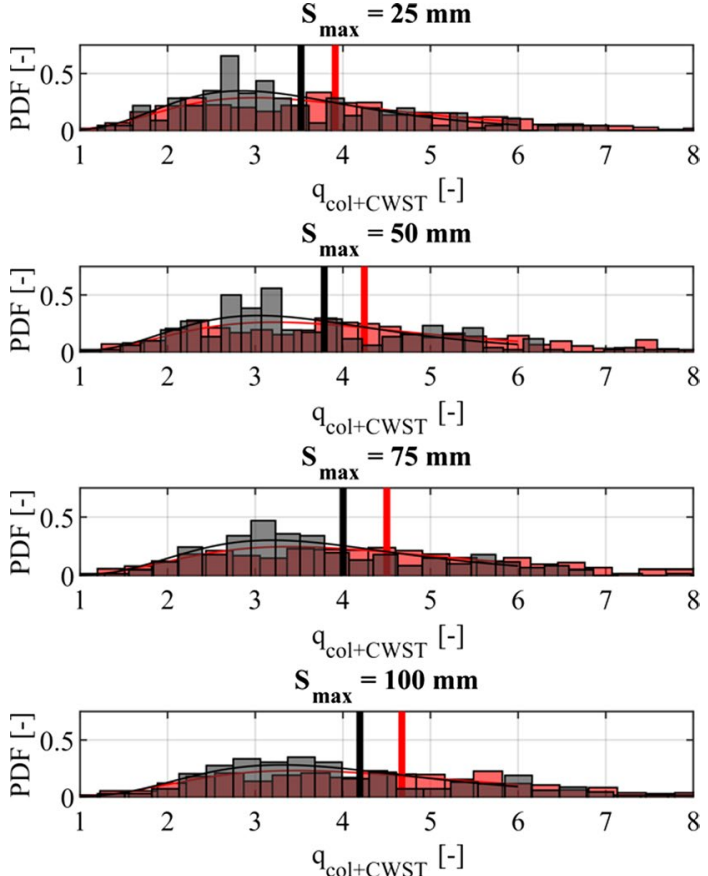

$\mathrm{q}_{\text {col+CWST }}{ }^{[-]}$
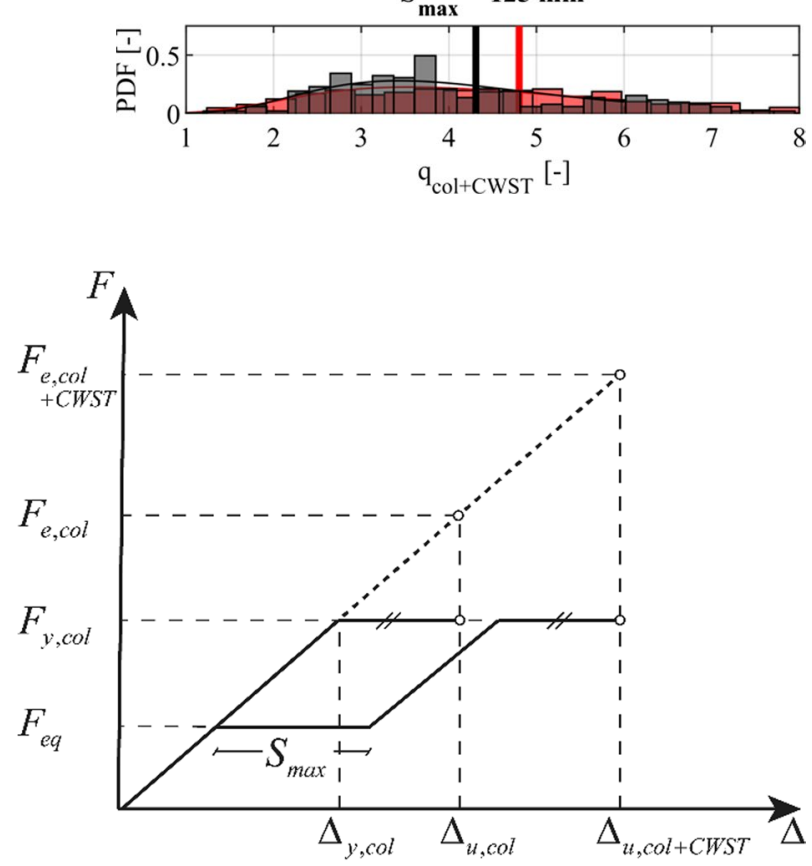

remember that in common design applications uniform hazard spectra are used, thus neglecting record to record variability. 


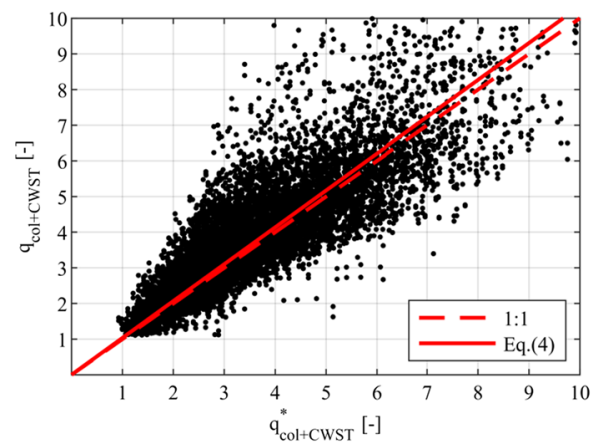

(a)

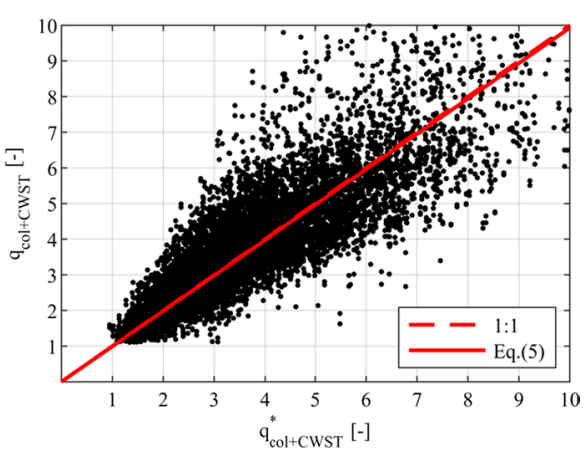

(b)

Fig. 15 Comparison between the behavior factor values obtained from IDA analyses $\left(q_{\text {col }+C W S T}\right)$ and form a Eqs. (4) to b (5). The dashed line has a unit slope coefficient while the solid line was obtained by linear regression

Fig. 16 Comparison between the distributions of $q_{\text {col }+C W S T}$ values obtained from IDA analyses and form Eqs. (4) to (5). See Fig. 11 for PDFs for pulse-like and nonpulse like ground motions

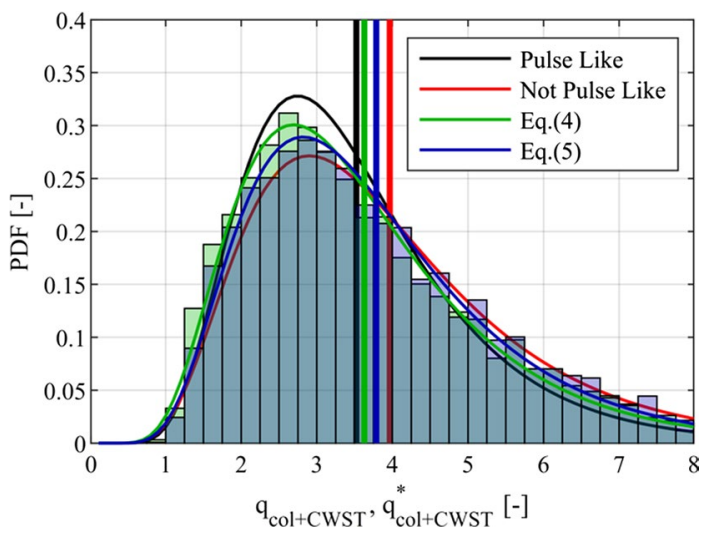

Finally, Table 10 reports the mean prediction error for of Eq. (5) compared to IDA results, for different values of $S_{\max }$ and for the different models. The maximum error on the average prediction is $9.5 \%$ for model C, ultimate chord rotation of $4.5 \%$ and $S_{\max }=125 \mathrm{~mm}$. Considering a range of $S_{\max }$ values between 25 and $75 \mathrm{~mm}$, which are reasonable values for existing structures, the maximum mean error is $8.3 \%$.

\section{Conclusions}

The paper discussed the results of nonlinear analyses aimed at evaluating the behavior factor associated to the introduction of CWSTs in beam-column joints of prefabricated structures, and presented a simplified approach to estimate the same behavior factor. Based on the results of the numerical analyses performed, the following conclusions can be drawn:

- In all the numerical simulations carried-out the maximum base shear in the frame models with dissipative devices was lower than the maximum base shear in the corresponding elastic models with hinged beam-column joints; 
Table 10 Mean error in behavior factor estimates given by Eq. (5) with respect to results of IDA analyses

\begin{tabular}{|c|c|c|c|c|c|c|c|}
\hline \multirow[t]{2}{*}{ Model } & \multirow[t]{2}{*}{$\theta_{u}(\%)$} & \multirow[t]{2}{*}{ Pulse } & \multicolumn{5}{|l|}{$S_{\max }$} \\
\hline & & & $25 \mathrm{~mm}(\%)$ & $50 \mathrm{~mm}(\%)$ & $75 \mathrm{~mm}(\%)$ & $100 \mathrm{~mm}(\%)$ & $125 \mathrm{~mm}(\%)$ \\
\hline \multirow[t]{4}{*}{ A } & \multirow[t]{2}{*}{3.00} & $\mathrm{P}$ & -6.8 & -6.7 & -6.6 & -6.5 & -6.5 \\
\hline & & $\mathrm{NP}$ & -6.8 & -6.9 & -6.7 & -6.4 & -6.0 \\
\hline & \multirow[t]{2}{*}{4.50} & $\mathrm{P}$ & -6.6 & -6.6 & -6.5 & -6.5 & -6.5 \\
\hline & & $\mathrm{NP}$ & -6.7 & -6.7 & -6.6 & -6.6 & -6.1 \\
\hline \multirow[t]{4}{*}{ B } & \multirow[t]{2}{*}{3.00} & $\mathrm{P}$ & 2.0 & 2.0 & 2.2 & 2.2 & 2.4 \\
\hline & & $\mathrm{NP}$ & 1.1 & 1.1 & 1.5 & 1.9 & 2.5 \\
\hline & \multirow[t]{2}{*}{4.50} & $\mathrm{P}$ & 2.1 & 2.2 & 2.3 & 2.4 & 2.5 \\
\hline & & $\mathrm{NP}$ & 1.8 & 2.0 & 2.4 & 2.8 & 3.2 \\
\hline \multirow[t]{4}{*}{$\mathrm{C}$} & \multirow[t]{2}{*}{3.00} & $\mathrm{P}$ & 8.0 & 8.0 & 8.1 & 8.2 & 8.4 \\
\hline & & $\mathrm{NP}$ & 7.4 & 7.6 & 8.1 & 8.6 & 9.4 \\
\hline & \multirow[t]{2}{*}{4.50} & $\mathrm{P}$ & 8.0 & 8.1 & 8.1 & 8.3 & 8.4 \\
\hline & & $\mathrm{NP}$ & 7.4 & 7.8 & 8.3 & 8.9 & 9.5 \\
\hline \multirow[t]{4}{*}{$\mathrm{C} 1$} & \multirow[t]{2}{*}{3.00} & $\mathrm{P}$ & 0.3 & 0.3 & 0.4 & 0.5 & 0.6 \\
\hline & & $\mathrm{NP}$ & 0.0 & 0.1 & 0.6 & 1.2 & 2.0 \\
\hline & \multirow[t]{2}{*}{4.50} & $\mathrm{P}$ & 0.4 & 0.4 & 0.5 & 0.6 & 0.8 \\
\hline & & $\mathrm{NP}$ & 0.1 & 0.4 & 0.9 & 1.4 & 2.2 \\
\hline \multirow[t]{4}{*}{ D } & \multirow[t]{2}{*}{3.00} & $\mathrm{P}$ & -1.7 & -1.7 & -1.6 & -1.6 & -1.5 \\
\hline & & $\mathrm{NP}$ & -1.9 & -1.9 & -1.7 & -1.3 & -0.9 \\
\hline & \multirow[t]{2}{*}{4.50} & $\mathrm{P}$ & -1.7 & -1.7 & -1.6 & -1.5 & -1.4 \\
\hline & & $\mathrm{NP}$ & -1.9 & -1.8 & -1.5 & -1.3 & -1.1 \\
\hline \multirow[t]{4}{*}{ D1 } & \multirow[t]{2}{*}{3.00} & $\mathrm{P}$ & -2.2 & -2.3 & -2.2 & -2.1 & -2.0 \\
\hline & & $\mathrm{NP}$ & -2.4 & -2.6 & -2.3 & -1.9 & -1.7 \\
\hline & \multirow[t]{2}{*}{4.50} & $\mathrm{P}$ & -2.2 & -2.2 & -2.1 & -2.0 & -1.9 \\
\hline & & $\mathrm{NP}$ & -2.4 & -2.3 & -2.0 & -1.9 & -1.7 \\
\hline
\end{tabular}

- Incremental Dynamic Analyses were carried out, considering 88 recorded accelerograms, different column ultimate chord rotations and maximum displacement capacities for the CWSTs as target damage levels. Form these analyses an equivalent behavior factor for structures equipped with the dissipative devices was estimated;

- The dependence of the behavior factor of structures with CWSTs on the maximum deformation capacity $\left(S_{\max }\right)$ of these latter was investigated, showing that the behavior factor increases as $S_{\max }$ increases;

- The results of IDA analyses indicated that the introduction of the CWSTs leads to an increased value of the behavior with respect to structures with hinged connections;

- The results of the analyses showed that the behavior factor for pulse-like ground motions is on average about $10 \%$ less than the behavior factor for non-pulse like ground motions;

- An approximated analytical approach was proposed to estimate behavior factor values for structures equipped with CWSTs in beam-column connections. Based on the results of IDA analysis the approximation of the simplified formula proposed is satisfactorily for CWSTs with $S_{\max }$ in the range $25-75 \mathrm{~mm}$. 
Funding Open access funding provided by Alma Mater Studiorum - Università di Bologna within the CRUI-CARE Agreement.

Open Access This article is licensed under a Creative Commons Attribution 4.0 International License, which permits use, sharing, adaptation, distribution and reproduction in any medium or format, as long as you give appropriate credit to the original author(s) and the source, provide a link to the Creative Commons licence, and indicate if changes were made. The images or other third party material in this article are included in the article's Creative Commons licence, unless indicated otherwise in a credit line to the material. If material is not included in the article's Creative Commons licence and your intended use is not permitted by statutory regulation or exceeds the permitted use, you will need to obtain permission directly from the copyright holder. To view a copy of this licence, visit http://creativecommons.org/licenses/by/4.0/.

\section{Appendix}

See Tables 11, 12 and 13.

Table 11 Ground motion recordings for the large magnitude short distance scenario (LMSD)

\begin{tabular}{|c|c|c|c|c|c|}
\hline Earthquake (Year) & Station name & Pulse like & $R_{J B}[\mathrm{~km}]$ & $M_{w}[-]$ & $\mathrm{PGA}_{\mathrm{h}} \cdot\left[\mathrm{m} / \mathrm{s}^{2}\right]$ \\
\hline Imperial Valley-02 (1940) & El Centro Array \#9 & 0 & 6.09 & 6.95 & 2.11 \\
\hline San Fernando (1971) & Pacoima Dam (upper left abut) & 0 & 0 & 6.61 & 12.03 \\
\hline Gazli, USSR (1976) & Karakyr & 0 & 3.92 & 6.8 & 5.97 \\
\hline Tabas, Iran (1978) & Dayhook & 0 & 0 & 7.35 & 3.98 \\
\hline Tabas, Iran (1978) & Tabas & 0 & 1.79 & 7.35 & 8.2 \\
\hline Imperial Valley-06 (1979) & EC Meloland Overpass FF & 0 & 0.07 & 6.53 & 2.9 \\
\hline Imperial Valley-06 (1979) & El Centro Array \#7 & 1 & 0.56 & 6.53 & 4.54 \\
\hline Irpinia, Italy-01 (1980) & Bagnoli Irpinio & 0 & 8.14 & 6.9 & 1.98 \\
\hline Irpinia, Italy-01 (1980) & Sturno & 1 & 6.78 & 6.9 & 2.46 \\
\hline Nahanni, Canada (1985) & Site 1 & 0 & 2.48 & 6.76 & 9.59 \\
\hline New Zealand-02 (1987) & Matahina Dam & 0 & 16.09 & 6.6 & 2.51 \\
\hline Superstition Hills-02 (1987) & Westmorland Fire Sta & 0 & 13.03 & 6.54 & 2.07 \\
\hline Loma Prieta (1989) & LGPC & 1 & 0 & 6.93 & 9.48 \\
\hline Cape Mendocino (1992) & Cape Mendocino & 1 & 0 & 7.01 & 14.69 \\
\hline Cape Mendocino (1992) & Petrolia & 1 & 0 & 7.01 & 6.5 \\
\hline Landers (1992) & Joshua Tree & 0 & 11.03 & 7.28 & 2.79 \\
\hline Landers (1992) & Lucerne & 0 & 2.19 & 7.28 & 7.13 \\
\hline Northridge-01 (1994) & Rinaldi Receiving Sta & 1 & 0 & 6.69 & 8.1 \\
\hline Northridge-01 (1994) & Sylmar-Olive View Med FF & 0 & 1.74 & 6.69 & 8.27 \\
\hline Kobe, Japan (1995) & KJMA & 0 & 0.94 & 6.9 & 8.06 \\
\hline Kobe, Japan (1995) & Port Island (0 m) & 1 & 3.31 & 6.9 & 3.09 \\
\hline Kocaeli, Turkey (1999) & Duzce & 0 & 13.6 & 7.51 & 3.51 \\
\hline Kocaeli, Turkey (1999) & Yarimca & 1 & 1.38 & 7.51 & 3.42 \\
\hline Chi-Chi, Taiwan (1999) & TCU052 & 0 & 0 & 7.62 & 4.11 \\
\hline Chi-Chi, Taiwan (1999) & TCU084 & 0 & 0 & 7.62 & 11.35 \\
\hline Duzce, Turkey (1999) & Bolu & 1 & 12.02 & 7.14 & 8.07 \\
\hline Duzce, Turkey (1999) & Duzce & 1 & 0 & 7.14 & 5.25 \\
\hline Manjil, Iran (1990) & Abbar & 0 & 12.56 & 7.37 & 4.87 \\
\hline Hector Mine (1999) & Hector & 0 & 10.35 & 7.13 & 3.3 \\
\hline Denali, Alaska (2002) & TAPS Pump Station \#10 & 1 & 0.18 & 7.9 & 3.13 \\
\hline Loma Prieta (1989) & Los Gatos-Lexington Dam & 0 & 3.22 & 6.93 & 4.24 \\
\hline
\end{tabular}


Table 12 Ground motion recordings for the large magnitude long distance scenario (LMLD)

\begin{tabular}{|c|c|c|c|c|c|}
\hline Earthquake (Year) & Station name & Pulse like & $R_{J B}[\mathrm{~km}]$ & $M_{w}[-]$ & $\mathrm{PGA}_{\mathrm{h}}\left[\mathrm{m} / \mathrm{s}^{2}\right]$ \\
\hline Borrego Mtn (1968) & El Centro Array \#9 & 0 & 45.12 & 6.63 & 1.28 \\
\hline San Fernando (1971) & LA-Hollywood Stor FF & 0 & 22.77 & 6.61 & 2.06 \\
\hline Imperial Valley-06 (1979) & Delta & 0 & 22.03 & 6.53 & 3.44 \\
\hline Superstition Hills-02 (1987) & Wildlife Liquef. Array & 0 & 23.85 & 6.54 & 2.03 \\
\hline Loma Prieta (1989) & Foster City_APEEL 1 & 0 & 43.77 & 6.93 & 2.89 \\
\hline Loma Prieta (1989) & Hollister-South and Pine & 0 & 27.67 & 6.93 & 3.63 \\
\hline Cape Mendocino (1992) & Eureka-Myrtle and West & 0 & 40.23 & 7.01 & 1.75 \\
\hline Landers (1992) & Desert Hot Springs & 0 & 21.78 & 7.28 & 1.51 \\
\hline Landers (1992) & North Palm Springs & 0 & 26.84 & 7.28 & 1.31 \\
\hline Landers (1992) & $\begin{array}{l}\text { S. Bernardino-E \& Hospital- } \\
\text { ity }\end{array}$ & 0 & 79.76 & 7.28 & 0.76 \\
\hline Landers (1992) & Yermo Fire Station & 0 & 23.62 & 7.28 & 2.4 \\
\hline Northridge-01 (1994) & Castaic_-Old Ridge Route & 0 & 20.1 & 6.69 & 5.04 \\
\hline Northridge-01 (1994) & LA-Baldwin Hills & 0 & 23.51 & 6.69 & 1.65 \\
\hline Northridge-01 (1994) & LA-Centinela St & 0 & 20.36 & 6.69 & 3.15 \\
\hline Northridge-01 (1994) & LA-Saturn St & 0 & 21.17 & 6.69 & 4.3 \\
\hline Kobe, Japan (1995) & Abeno & 1 & 24.85 & 6.9 & 2.3 \\
\hline Kobe, Japan (1995) & Kakogawa & 0 & 22.5 & 6.9 & 3.38 \\
\hline Kobe, Japan (1995) & Morigawachi & 1 & 24.78 & 6.9 & 2.1 \\
\hline Kobe, Japan (1995) & Yae & 1 & 27.77 & 6.9 & 1.55 \\
\hline Kocaeli, Turkey (1999) & Ambarli & 0 & 68.09 & 7.51 & 1.81 \\
\hline Kocaeli, Turkey (1999) & Bursa Tofas & 0 & 60.43 & 7.51 & 1.06 \\
\hline Kocaeli, Turkey (1999) & Iznik & 0 & 30.74 & 7.51 & 1.34 \\
\hline Chi-Chi, Taiwan (1999) & HWA013 & 0 & 50.51 & 7.62 & 1.39 \\
\hline Chi-Chi, Taiwan (1999) & ILA037 & 0 & 81.7 & 7.62 & 0.94 \\
\hline Chi-Chi, Taiwan (1999) & TAP017 & 0 & 97.69 & 7.62 & 1.04 \\
\hline Chi-Chi, Taiwan (1999) & TCU117 & 0 & 25.44 & 7.62 & 1.17 \\
\hline Manjil, Iran (1990) & Abhar & 0 & 75.58 & 7.37 & 2.05 \\
\hline Manjil, Iran (1990) & Rudsar & 0 & 63.96 & 7.37 & 0.84 \\
\hline Manjil, Iran (1990) & Tonekabun & 0 & 93.3 & 7.37 & 1.34 \\
\hline Hector Mine (1999) & Amboy & 0 & 41.82 & 7.13 & 1.78 \\
\hline Hector Mine (1999) & $\begin{array}{l}\text { Indio-Riverside Co Fair } \\
\text { Grnds }\end{array}$ & 0 & 74 & 7.13 & 1.21 \\
\hline Hector Mine (1999) & Joshua Tree & 0 & 31.06 & 7.13 & 1.43 \\
\hline
\end{tabular}


Table 13 Ground motion recordings for the small magnitude short distance scenario (SMSD)

\begin{tabular}{lllllc}
\hline Earthquake (Year) & Station Name & Pulse like & $R_{J B} \cdot[\mathrm{km}]$ & $M_{w} \cdot[-]$ & $\mathrm{PGA}_{\mathrm{h}}\left[\mathrm{m} / \mathrm{s}^{2}\right]$ \\
\hline $\begin{array}{l}\text { Managua, Nicaragua-01 } \\
\text { (1972) }\end{array}$ & Managua, ESSO & 0 & 3.51 & 6.24 & 3.31 \\
Coyote Lake (1979) & Gilroy Array \#2 & 0 & 8.47 & 5.74 & 3.33 \\
Coyote Lake (1979) & Gilroy Array \#6 & 0 & 0.42 & 5.74 & 4.26 \\
Mammoth Lakes-01 (1980) & Convict Creek & 0 & 1.1 & 6.06 & 4.09 \\
Victoria, Mexico (1980) & Cerro Prieto & 0 & 13.8 & 6.33 & 6.09 \\
Victoria, Mexico (1980) & Chihuahua & 0 & 18.53 & 6.33 & 1.47 \\
Irpinia, Italy-02 (1980) & Calitri & 0 & 8.81 & 6.2 & 1.74 \\
Westmorland (1981) & Parachute Test Site & 1 & 16.54 & 5.9 & 2.37 \\
Westmorland (1981) & Westmorland Fire Sta & 1 & 6.18 & 5.9 & 3.61 \\
Coalinga-01 (1983) & Pleasant Valley P.P.-bldg & 0 & 7.69 & 6.36 & 3.72 \\
Coalinga-01 (1983) & Pleasant Valley P.P.-yard & 0 & 7.69 & 6.36 & 5.8 \\
Morgan Hill (1984) & Coyote Lake Dam (SW & 1 & 0.18 & 6.19 & 12.74 \\
& Abut) & & & & \\
Morgan Hill (1984) & Gilroy Array \#4 & 0 & 11.53 & 6.19 & 2.2 \\
Morgan Hill (1984) & Gilroy Array \#6 & 0 & 9.85 & 6.19 & 2.86 \\
Morgan Hill (1984) & Halls Valley & 0 & 3.45 & 6.19 & 3.06 \\
N. Palm Springs (1986) & Morongo Valley & 0 & 3.67 & 6.06 & 2.14 \\
N. Palm Springs (1986) & North Palm Springs & 0 & 0 & 6.06 & 5.83 \\
Chalfant Valley-02 (1986) & Zack Brothers Ranch & 0 & 6.44 & 6.19 & 4.38 \\
San Salvador (1986) & National Geografical Inst & 1 & 3.71 & 5.8 & 3.99 \\
Dinar, Turkey (1995) & Dinar & 0 & 0 & 6.4 & 3.45 \\
Chi-Chi, Taiwan-03 (1999) & CHY024 & 0 & 18.47 & 6.2 & 1.83 \\
Chi-Chi, Taiwan-03 (1999) & TCU122 & 0 & 18.1 & 6.2 & 1.97 \\
Chi-Chi, Taiwan-03 (1999) & TCU129 & 0 & 10.95 & 6.2 & 9.33 \\
Chi-Chi, Taiwan-04 (1999) & CHY074 & 0 & 6.02 & 6.2 & 3.17 \\
Chi-Chi, Taiwan-06 (1999) & TCU080 & 1 & 0 & 6.3 & 5.27 \\
\hline & & & & & \\
\hline
\end{tabular}

\section{References}

Babič A, Dolšek M (2016) Seismic fragility functions of industrial precast building classes. Eng Struct 118:357-370. https://doi.org/10.1016/j.engstruct.2016.03.069

Baker JW (2007) Quantitative classification of near-fault ground motions. Bull Seismol Soc Am 97:1486-1501

Belleri A, Brunesi E, Nascimbene R et al (2015) Seismic performance of precast industrial facilities following major earthquakes in the italian territory. J Perform Constr Facil 29:04014135. https://doi. org/10.1061/(ASCE)CF.1943-5509.0000617

Belleri A, Marini A, Riva P, Nascimbene R (2017) Dissipating and re-centring devices for portal-frame precast structures. Eng Struct 150:736-745. https://doi.org/10.1016/j.engstruct.2017.07.072

Bellotti D, Casotto C, Crowley H et al (2014) Capannoni monopiano prefabbricati: distribuzione probabilistica dei sistemi e sottosistemi strutturali dagli anni sessanta ad oggi (in Italian). Progett Sismica 5:41-70. https://doi.org/10.7414/PS.5.3.41-70

Biondini F, Dal Lago B, Toniolo G (2013) Role of wall panel connections on the seismic performance of precast structures. Bull Earthq Eng 11:1061-1081. https://doi.org/10.1007/s10518-012-9418-Z 
Biondini F, Titi A, Toniolo G (2013b) Prestazioni sismiche di strutture prefabbricate con connessioni trave-pilastro ad attrito. In: Proceedings of the XV conference of the italian association of seismic engineering (ANIDIS). Padua, Italy, 30 June - 4 July

Bommer JJ, Acevedo AB (2004) The use of real earthquake accelerograms as input to dynamic analysis. J Earthq Eng 8:43-91

Bournas DA, Negro P, Taucer FF (2013) Performance of industrial buildings during the Emilia earthquakes in Northern Italy and recommendations for their strengthening. Bull Earthq Eng 12:23832404. https://doi.org/10.1007/s10518-013-9466-z

Bovo M, Buratti N (2019) Evaluation of the variability contribution due to epistemic uncertainty on constitutive models in the definition of fragility curves of RC frames. Eng Struct 188:700-716. https:// doi.org/10.1016/j.engstruct.2019.03.064

Bradley BA (2013) A critical examination of seismic response uncertainty analysis in earthquake engineering. Earthq Eng Struct Dyn 42:1717-1729. https://doi.org/10.1002/eqe.2331

Buratti N, Minghini F, Ongaretto E et al (2017) Empirical seismic fragility for the precast RC industrial buildings damaged by the 2012 Emilia (Italy) earthquakes. Earthq Eng Struct Dyn 46:2317-2335. https://doi.org/10.1002/eqe.2906

Dal Lago B, Biondini F, Toniolo G (2017a) Friction-based dissipative devices for precast concrete panels. Eng Struct 147:356-371. https://doi.org/10.1016/J.ENGSTRUCT.2017.05.050

Dal Lago B, Biondini F, Toniolo G (2017b) Experimental Investigation on Steel W-Shaped Folded Plate Dissipative Connectors for Horizontal Precast Concrete Cladding Panels. J Earthq Eng. https://doi. org/10.1080/13632469.2016.1264333

Dal Lago B, Toniolo G, Felicetti R, Lamperti Tornaghi M (2017c) End support connection of precast roof elements by bolted steel angles. Struct Concr. https://doi.org/10.1002/suco.201600218

Del Monte E, Falsini C, Boschi S et al (2019) An innovative cladding panel connection for RC precast buildings. Bull Earthq Eng 17:845-865. https://doi.org/10.1007/s10518-018-0470-1

Demartino C, Vanzi I, Monti G, Sulpizio C (2018) Precast industrial buildings in Southern Europe: loss of support at frictional beam-to-column connections under seismic actions. Bull Earthq Eng 16:259-294. https://doi.org/10.1007/s10518-017-0196-5

Deyanova MG, Pampanin S, Nascimbene R (2014) Assessment of single-storey precast concrete industrial buildings with hinged beam-column connections with and without dowels. In: Second European conference on earthquake engineering and seismology, Istanbul. Istanbul, Turkey, 25-29 August

Guerrini G, Graziotti F, Penna A, Magenes G (2017) Improved evaluation of inelastic displacement demands for short-period masonry structures. Earthq Eng Struct Dyn 46:1411-1430. https://doi. org/10.1002/eqe. 2862

Jalayer F, Cornell CA (2009) Alternative non-linear demand estimation methods for probability-based seismic assessments. Earthq Eng Struct Dyn 38:951-972. https://doi.org/10.1002/eqe.876

Liberatore L, Sorrentino L, Liberatore D, Decanini LD (2013) Failure of industrial structures induced by the Emilia (Italy) 2012 earthquakes. Eng Fail Anal 34:629-647. https://doi.org/10.1016/j.engfa ilanal.2013.02.009

Ligabue V, Bovo M, Savoia M (2014) Connessioni tegolo-trave: studio sperimentale e numerico del comportamento di angolari di collegamento (in Italian). In: Proceedings of workshop "Tecniche innovative per il miglioramento sismico di edifici prefabbricati.” Bologna, Italy, 22 October 2014

MacRae GA, Morrow DV, Roeder CW (2001) Near-fault ground motion effects on simple structures. J Struct Eng 127:996-1004. https://doi.org/10.1061/(ASCE)0733-9445(2001)127:9(996)

Magliulo G, Capozzi V, Fabbrocino G, Manfredi G (2011) Neoprene-concrete friction relationships for seismic assessment of existing precast buildings. Eng Struct 33:532-538. https://doi.org/10.1016/j. engstruct.2010.11.011

Magliulo G, Ercolino M, Petrone C et al (2014) The emilia earthquake: seismic performance of precast reinforced concrete buildings. Earthq Spectra 30:891-912. https://doi.org/10.1193/091012EQS2 $85 \mathrm{M}$

Mandelli Contegni M, Palermo A, Toniolo G (2008) Strutture prefabbricate: schedario di edifici prefabbricati in C.A. (in Italian)

Mander JB, Priestley MJN, Park R (1989) Theoretical stress-strain model for confined concrete. J Struct Eng 114:1804-1826

Marinini L, Spatti P, Riva P, Nascimbene R (2011) Strutture prefabbricate: moderni sistemi di protezione antisismica (in Italian). Progett sismica 3:23-44

Martinelli P, Mulas MG (2010) An innovative passive control technique for industrial precast frames. Eng Struct 32:1123-1132. https://doi.org/10.1016/j.engstruct.2009.12.038 
Mavroeidis GP, Dong G, Papageorgiou AS (2004) Near-fault ground motions, and the response of elastic and inelastic single-degree-of-freedom (SDOF) systems. Earthq Eng Struct Dyn 33:1023-1049

McKenna F, Scott MH, Fenves GL (2010) Nonlinear finite-element analysis software architecture using object composition. J Comput Civil Eng 24(1):95-107. https://doi.org/10.1061/(ASCE)CP.19435487.0000002

Muciaccia G, Cervio M, Franzoso M, Veneziano M (2014) Utilizzo di ancoraggi post-inseriti in interventi di recupero di capannoni industriali in zona sismica (in Italian). In: Proceedings of Workshop "Tecniche innovative per il miglioramento sismico di edifici prefabbricati.” Bologna, Italy, 22 October 2014

Pollini AV, Buratti N, Mazzotti C (2018) Experimental and numerical behaviour of dissipative devices based on carbon-wrapped steel tubes for the retrofitting of existing precast RC structures. Earthq Eng Struct Dyn. https://doi.org/10.1002/eqe.3017

Priestley MJN, Calvi GM, Kowalsky MJ (2007) Displacement based seismic design of structures. IUSS Press, Pavia

Reza Mehryari Lima, Ismarrubie ZN, Zainudin ES, Tang SH (2011) Axial behavior of steel tube wrapped by composite as energy absorber under compressive load. In: 2011 IEEE symposium on business, engineering and industrial applications (ISBEIA). IEEE, pp 10-15

Rossi L, Holtschoppen B, Butenweg C (2019) Official data on the economic consequences of the 2012 Emilia-Romagna earthquake: a first analysis of database SFINGE. Bull Earthq Eng 17:4855-4884. https://doi.org/10.1007/s10518-019-00655-8

Savoia M, Buratti N, Vincenzi L (2017) Damage and collapses in industrial precast buildings after the 2012 Emilia earthquake. Eng Struct 137:162-180. https://doi.org/10.1016/j.engstruct.2017.01.059

Scotta R, De Stefani L, Vitaliani R (2015) Passive control of precast building response using cladding panels as dissipative shear walls. Bull Earthq Eng 13:3527-3552. https://doi.org/10.1007/s10518-015-9763-9

Song H-W, Wan Z-M, Xie Z-M, Du X-W (2000) Axial impact behavior and energy absorption efficiency of composite wrapped metal tubes. Int J Impact Eng 24:385-401. https://doi.org/10.1016/S0734 $-743 X(99) 00165-7$

Titi A, Biondini F, Toniolo G (2018) Seismic assessment of existing precast structures with dry-friction beam-to-column joints. Bull Earthq Eng 16:2067-2086. https://doi.org/10.1007/s10518-017-0271-y

Publisher's Note Springer Nature remains neutral with regard to jurisdictional claims in published maps and institutional affiliations. 